\title{
Biogas Production from Organic Wastes: Integrating Concepts of Circular Economy
}

\author{
Marcos Ellacuriaga ${ }^{1}$, José García-Cascallana ${ }^{1}$ and Xiomar Gómez ${ }^{2, *(D)}$ \\ 1 Department of Applied Chemistry and Physics, School of Industrial Engineering, Campus de Vegazana, \\ University of León, 24071 León, Spain; marcosellacuriaga@gmail.com (M.E.); jogaca0504@gmail.com (J.G.-C.) \\ 2 Chemical and Environmental Bioprocess Engineering Group, Department of Applied Chemistry and Physics, \\ Natural Resources Institute (IRENA), University of León, Av. de Portugal 41, 24071 León, Spain \\ * Correspondence: xagomb@unileon.es; Tel.: +34-987-295-349
}

Citation: Ellacuriaga, M.;

García-Cascallana, J.; Gómez, X. Biogas Production from Organic Wastes: Integrating Concepts of Circular Economy. Fuels 2021, 2, 144-167. https://doi.org/10.3390/ fuels2020009

Academic Editor: Maria A. Goula

Received: 24 March 2021

Accepted: 27 April 2021

Published: 29 April 2021

Publisher's Note: MDPI stays neutral with regard to jurisdictional claims in published maps and institutional affiliations.

Copyright: (C) 2021 by the authors. Licensee MDPI, Basel, Switzerland. This article is an open access article distributed under the terms and conditions of the Creative Commons Attribution (CC BY) license (https:// creativecommons.org/licenses/by/ $4.0 /)$.

\begin{abstract}
Anaerobic digestion is traditionally used for treating organic materials. This allows the valorization of biogas and recycling of nutrients thanks to the land application of digestates. However, although this technology offers a multitude of advantages, it is still far from playing a relevant role in the energy market and from having significant participation in decarbonizing the economy. Biogas can be submitted to upgrading processes to reach methane content close to that of natural gas and therefore be compatible with many of its industrial applications. However, the high installation and operating costs of these treatment plants are the main constraints for the application of this technology in many countries. There is an urgent need of increasing reactor productivity, biogas yields, and operating at greater throughput without compromising digestion stability. Working at organic solid contents greater than $20 \%$ and enhancing hydrolysis and biogas yields to allow retention times to be around 15 days would lead to a significant decrease in reactor volume and therefore in initial capital investments. Anaerobic digestion should be considered as one of the key components in a new economy model characterized by an increase in the degree of circularity. The present manuscript reviews the digestion process analyzing the main parameters associated with digestion performance. The novelty of this manuscript is based on the link established between operating reactor conditions, optimizing treatment capacity, and reducing operating costs that would lead to unlocking the potential of biogas to promote bioenergy production, sustainable agronomic practices, and the integration of this technology into the energy grid.
\end{abstract}

Keywords: anaerobic digestion; waste valorization; reactor productivity; high-solid digestion; solidphase digestion; thermophilic conditions; pretreatments

\section{Introduction}

The recycling of materials, energy, and nutrients is undoubtedly a reasonable way to increase the efficiency of processes. Recycling allows better use of resources, which can be improved by optimizing energy demand and the use of raw materials. However, infinite recycling of any quantity is not possible due to the intrinsic thermodynamics limits. Absolute circularity in any transformation process is hopeless because in each cycle, there is a loss in the quality and quantity of the material, which is unavoidable, as stated by the second thermodynamic law [1]. Therefore, the idea of a circular economy is more often celebrated, instead of being critically analyzed by the scientific community, since its implementation results are limited and fragile because the circular economy is achieved mostly through global recycling networks [2]. These fluxes involve a substantial amount of energy and additional resources necessary to recover lower quality materials and mixed products.

In the world, about $75 \%$ of the energy production is based on non-renewable sources, and this energy is obtained through the combustion of releasing gas emissions into the atmosphere [3]. When the global consumption of energy along with the current price of 
renewable energy production is considered, results show that attempts of covering all this demand exclusively through the production of renewable energy and recycling of material are not reasonable. A more serious analysis is needed regarding the efficiency of cycles and strategies for recovering energy. In addition, obtaining energy from waste materials is not stated as the primary option as established in the Circular Economy Action Plan [4].

Reducing the volume of wastes produced along with the valorization of low-quality streams is an integral part of production lines. This principle is in accordance with the circular economy and sustainability of industrial activities. However, obtaining valuable products from waste streams may not always be possible, at least at a rate ideally expected. Waste valorization processes need to take into account waste dispersion, transportation costs, and all the different treatment units involved in recovering valuable components and equipment associated with its transformation; in addition, the price of virgin raw material greatly affects the behavior of recycled components. The energy demand and the number of resources involved in some cases may even be greater than those associated with the conversion of new raw materials. This highlights the need in establishing indicators capable of assessing any advancement gained when evaluating the efficiency of processes. These indicators should consider the reduction, reuse, and recycling of materials along with the capacity of valorizing wastes generated in a way that would make them useful in determining the approximation to the circular economy model when proposing any new value-chain [5]. Thus, the attempt should be to get as close as possible to the circular model, considering the optimization of energy and resource demand as the intrinsic limit for implementing this approach.

Wastewater treatment plants (WWTP) and waste treatment centers should have a role of particular importance if circular economy objectives are to be implemented. These installations offer the possibility of obtaining valuable materials and energy [6]. Anaerobic digestion is widely applied for the treatment of the organic fraction of municipal solid wastes (OFMSW) and producing bioenergy. Biogas obtained from the decomposition of organics has a high energy content and is usually used as fuel for producing heat and electricity. The presence of improper materials in organic wastes and in some cases, high concentrations of heavy metals, translates into a plant design of high complexity needing special pre-treatment units for preparing a homogenous feeding slurry. We should also add the intrinsic difficulty of separating inert materials and avoiding the presence of toxic elements in digestates that prevents any agronomic use [7].

Anaerobic digestion is a process that usually involves the recovery of energy from organics and allows the recycling of nutrients when digestates are applied on agricultural lands. From the time of the Industrial Revolution onward, the linear economy has been the predominant production way in modern society based on the consumer model where natural resources are the base of the system. The sequence of production, consumption, and final disposal has been considered as the logical way for developing the economy [8]. Now that society is struggling to move toward sustainability and developing a green energy production industry, these two aspects have become a part of the main issues of debate. Waste management is still considered a relevant problem, and this is particularly true if we take into account the global amount of wastes produced and the alternatives available for attaining a decrease in waste production. The reuse of materials, repair, and further reintegration into other production and consumption chains should be a key feature when creating new processing facilities [9]. The reevaluation of production schemes is being performed, and in this analysis, biological processes capable of recovering materials and revalorizing low-quality inputs at a high rate but also having a low demand for energy are the most suitable candidates for playing a major role.

There are several manuscripts available in the literature reporting the relevant role that anaerobic digestion should exert in a circular economy model, considering the capability of this process for producing energy from organics, manures, and a great diversity of agronomic wastes [10-13]. Table 1 lists the products associated with the role of anaerobic digestion in the circular economy based on scientific literature. These publications set the 
focus on the capacity of this process to produce energy and obtain additional valuable products when the process is integrated with other technologies, as it is the thermal treatment of digestate, or the conversion of side streams to produce liquid biofuels and mineral fertilizers from the precipitation of salts present in the digester liqueur. However, given the benefits this biological transformation offers, their implementation in different countries is not equally expanded. In many of these countries, the need for excessive governmental subsidies has resulted in installing this technology only during the specific periods where these tariffs offer the highest return of investment. Therefore, it is a priority to give a feasible solution to all the different factors extensively analyzed by several authors and to the difficulties that the digestion process encounters to become a successful alternative for waste management [14-16].

Table 1. The role of anaerobic digestion in the circular economy model. AD: anaerobic digestion, UASB: up-flow anaerobic sludge blanket, WWTP: wastewater treatment plant, CHP: combined heat and power.

\begin{tabular}{|c|c|c|c|}
\hline Material & Contribution & Proposed Model & Reference \\
\hline Organic solid wastes & $\begin{array}{l}\text { Biogas, hydrogen } \\
\text { VFA, lactic acid } \\
\text { Nutrient recovery }\end{array}$ & $\begin{array}{l}\text { Co-digestions and } \\
\text { multiple product } \\
\text { recovery }\end{array}$ & [17] \\
\hline Lipid-rich wastes & Bioenergy & $\begin{array}{c}\text { Pre-treatment }+ \\
\text { biomass retention } \\
\text { digestion system }\end{array}$ & [18] \\
\hline $\begin{array}{c}\text { Agricultural + } \\
\text { livestock wastes }\end{array}$ & $\begin{array}{l}\text { Energy, liquid fuels, } \\
\text { mineral fertilizers } \\
\text { (struvite), biopolymers, } \\
\text { fibers, char }\end{array}$ & Biorefinery concept & [8] \\
\hline $\begin{array}{l}\text { Livestock wastes + } \\
\text { agricultural residues }\end{array}$ & Energy, biochar & $\mathrm{AD}+$ pyrolysis & [19] \\
\hline Food wastes & Biogas & $\begin{array}{c}\text { UASB reactor + Natural } \\
\text { zeolites }\end{array}$ & [20] \\
\hline Yard wastes & $\begin{array}{l}\text { Energy from biogas and } \\
\text { hydrochar }\end{array}$ & $\begin{array}{l}\text { Thermal pre-treatment } \\
+\mathrm{AD}+\text { hydrothermal } \\
\text { treatment }\end{array}$ & {$[21,22]$} \\
\hline $\begin{array}{l}\text { Municipal food } \\
\text { wastes (MFW) }\end{array}$ & $\begin{array}{l}\text { Biogas and liquid } \\
\text { biofertilizer }\end{array}$ & $\begin{array}{c}\text { Hydromechanical } \\
\text { pretreated MFW + AD }\end{array}$ & [23] \\
\hline Sewage sludge & Energy using $\mathrm{CHP}$ & AD in WWTP & [6] \\
\hline Swine manure & $\begin{array}{l}\text { Energy and nutrient } \\
\text { recovery (liquid } \\
\text { fraction and digestate) }\end{array}$ & $\mathrm{AD}$ & [10] \\
\hline Municipal wastes & $\begin{array}{l}\text { Recycled material, } \\
\text { Biogas, landfill cover }\end{array}$ & $\begin{array}{c}\text { Separate collection } \\
\text { system + AD + land fill }\end{array}$ & [24] \\
\hline
\end{tabular}

In this manuscript, a description of the digestion technology and alternatives for improving biogas productivity and reducing digester size are analyzed as a way for reducing initial investment costs and enhancing treatment capacity. An introduction to the basics aspects of anaerobic digestion is presented along with different strategies found in the literature to improve performance and the expected effect on the digestion process. There exists a clear link between operating conditions and the response of microbial biomass, which translates into greater methane yields and thus economic benefits. It highlights the need for increasing process efficiency, which is crucial for making anaerobic digestion a key technology for producing bioenergy in the new circular economy model. The novelty of this manuscript is based on the analysis performed on the process operating conditions, the possibilities of optimizing the plant treatment capacity, and ways for reducing operating 
costs. These three parameters should be perfectly matched to increase digestion efficiency, the potential of biogas and favor sustainable agronomic practices, thus promoting its integration into the energy network.

\section{Anaerobic Transformation of Organics}

Anaerobic digestion is a technology with wide application in the degradation and stabilization of organics. Under anaerobic conditions, the material is oxidized and transformed into biogas and a liquid slurry containing the remaining compounds non-susceptible to anaerobic degradation along with components derived from microbial metabolism. The process involves several reaction mechanisms where anaerobic bacteria and archaea species transform biomass into a sequence of biological reactions. The performance of the reactor and the effect of inhibitory components have been extensively studied to find correlations between process parameters and microbial communities. Ziganshin et al. [25] studied bacterial communities in anaerobic reactors. These authors reported that bacterial subcommunities were highly diverse. The composition could not be correlated with parameters determining reactor performance, and dominant phylotypes were affiliated to Bacteroidetes. However, the archaeal subcommunities found in the reactor were characterized by being less diverse and correlated well with the performance of the reactor, and they were highly influenced by the effect of iron additives destined to suppress hydrogen sulfide evolution. Langer et al. [26] studied microbial communities in nine full-scale biogas plants applying different inputs and changing process parameters. These authors demonstrated the high correlation between microbial biomass and process parameters, indicating that ammonia concentration highly affected bacterial communities, whereas archaea were mostly affected by process temperature. On the other hand, the abundance of fungi was linked to the type of feedstock supplied. Thus, these authors showed the relevance of controlling digestion parameters to guarantee successful performance.

Temperature, organic loading, and residence time greatly determine the successful outcome of anaerobic digestion [27]. Both organic loading and residence time relies upon available active biomass inside the reactor and its capacity to degrade the incoming material. Temperature accelerates the rate of degradation, leading to a shorter time needed to complete the full conversion of the substrate. There are several reports in the literature describing the influence of these parameters when operating under mesophilic and thermophilic regimens [28-30] and successfully evaluating different types of wastes, such as swine manure [31,32], sewage sludge $[6,33,34]$, and lipid-rich wastes such as slaughterhouse wastes $[35,36]$. However, digestion is a complex process and may suffer from instabilities that are mainly associated with accidental overloading in the form of the presence of inhibitors such as sulfur compounds, high ammonia concentration, and volatile fatty acids (VFAs), or inadequate temperature control. The usual operational remedy is a rapid increase in hydraulic retention time (HRT) [37], the cease of feeding, $\mathrm{pH}$ control, or re-inoculation from a healthy reactor, if any of the other strategies result insufficient for preventing acid accumulation and $\mathrm{pH}$ drop. However, this last one is excessively costly.

\subsection{Description of the Digestion Process}

The basic reaction sequences of anaerobic digestion consider an initial hydrolysis stage for the solubilization of particulate organics. Biopolymers (carbohydrates, proteins, and lipids) are hydrolyzed and transformed into organic monomers. These small molecules are used as a substrate by fermentative organisms, as it is the case for amino acids and sugars, or they are used by anaerobic oxidizers in the case of fatty acids [38]. This first stage is usually assumed to follow first-order kinetics and is considered the limiting step in converting complex organics into biogas [39]. Acidogenesis is the subsequent stage where VFAs are produced, but if acidification is too fast, the accumulation of these acids may risk the whole process due to acute $\mathrm{pH}$ drop [28] or excessive concentration of these compounds in the reactor. These acids along with hydrogen $\left(\mathrm{H}_{2}\right)$, which is also formed in this stage, serve as precursors for methane formation [40]. Figure 1 presents a simplified schematization of the 
process considering biogas valorization and possible uses for digestate. A representation of the typical evolution of methane production curves under batch conditions is also included.

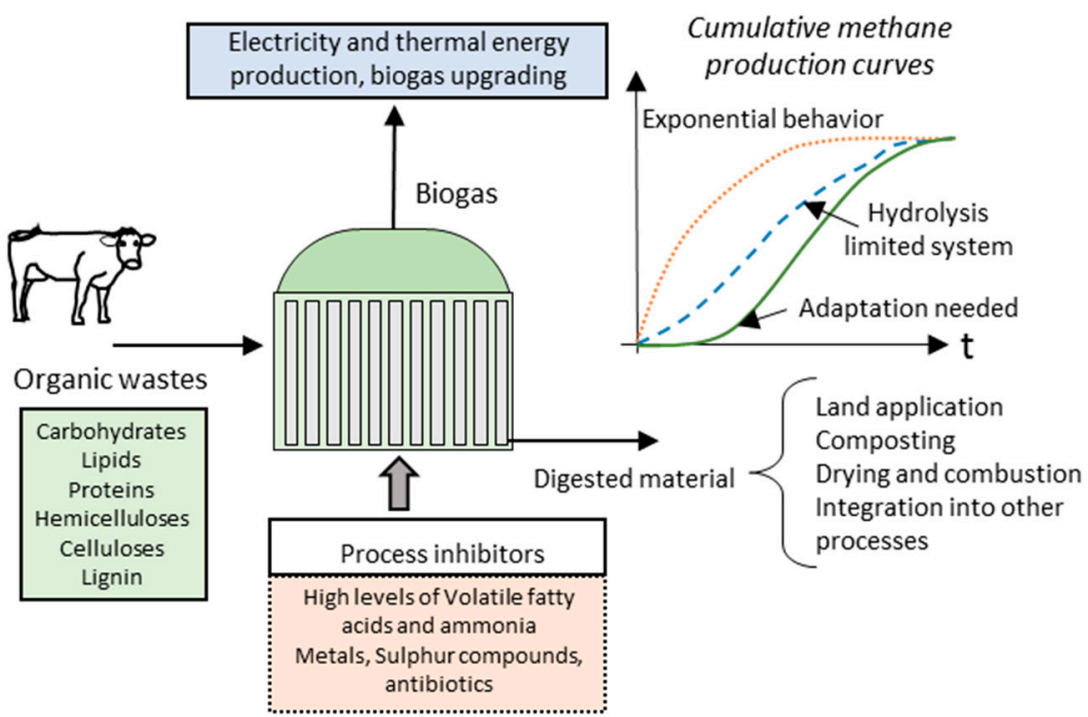

Figure 1. Schematic representation of the digestion process indicating main components of organics along with biogas and digested material derived from the process. A representation of common behavior of cumulative biogas production curves obtained under batch tests is also included.

The next stage in anaerobic digestion is the assimilation of organic acids having more than two carbons by acetogenic organisms into acetic acid, hydrogen, and carbon dioxide $[27,41]$. Acetogens have a low growth rate and are sensitive to process fluctuations [42], explaining the presence of hydrogen in biogas when an unbalance is experienced. In fact, a sudden increase in organic loading may cause VFA build-up and $\mathrm{H}_{2}$ accumulation in the reactor, in addition to a decrease in $\mathrm{pH}$ if this effect is high enough to overcome the buffering capacity of the system. Whitmore et al. [43] reported $\mathrm{H}_{2}$ gas in the reactor liqueur as a response to overloading conditions, indicating that even though values observed were greater than those established as inhibitory $(<0.10 .2 \mu \mathrm{M})$ for propionate and butyrate oxidation, the process sequence was capable of continuing thanks to the availability of the microflora to find microniches where oxidizing bacteria can proceed.

The optimum value of $\mathrm{pH}$ for fermentative bacteria is in the range of 5.5 to 6.5 , whereas higher $\mathrm{pH}$ values (6.8-7.6) are more adequate for syntrophic acetogenic bacteria and methanogens [44]. However, under normal operating conditions, digesters are usually run at values close to neutrality and even higher, up to 8.5, if the nitrogen content of the feed is high enough to cause elevated ammonium levels in the reactor liqueur. Syntrophic acetogenic bacteria are responsible for oxidizing short-chain fatty acids and ethanol into compounds that methanogens can assimilate. This degradation is thermodynamically unfavorable; thus, hydrogen and formate should be maintained at low levels by hydrogen/formate-consuming methanogens [44]. The final stage is called methanogenesis. Methane $\left(\mathrm{CH}_{4}\right)$ is mainly obtained from acetate, or hydrogen $\left(\mathrm{H}_{2}\right)$ and carbon dioxide $\left(\mathrm{CO}_{2}\right)$, or formate. In this stage, $\mathrm{H}_{2}$ is used as an electron acceptor by hydrogenotrophic methanogens. Many methanogens capable of using $\mathrm{H}_{2}$ also use formate as an electron donor, attaining the reduction of $\mathrm{CO}_{2}$ into $\mathrm{CH}_{4}$ [38]. However, methane is not the only reduced product obtained in anaerobic digestion. Sulfur, metal oxides, and humic substances can act as final electron acceptors in these environments [45]. Given the complexity of syntrophic relations between the different anaerobic microflora, the performance of the digester is then highly affected by several parameters in addition to the basic ones, as it would be the type of substrate, feeding rate, and HRT. Other factors are associated with reactor dynamics, as digestate liqueur solid content, mixing rate, and the use of supplements to favor the growth of certain species or interspecies electron transfer. 


\subsection{Increasing Biomass Activity as a Strategy for Improving Performance}

Recent studies proposed the intensification of methane production by adding $\mathrm{H}_{2}$ or by inoculating hydrogen-producing organisms to the anaerobic culture to favor $\mathrm{H}_{2}$ levels inside the reactor as was initially proposed by Bagi et al. [46]. At first sight, it may seem contradictory with the requirement of keeping low $\mathrm{H}_{2}$ levels in the reactor liqueur. Results regarding this protocol are extremely disperse, obtaining a great diversity of effects in the anaerobic microflora. Martínez et al. [33] reported improvements in biogas production with the addition of $\mathrm{H}_{2}$ gas into a digester treating sewage sludge. Still, the increase in biogas yield was mainly explained by the activity of homoacetogenic microbes, causing the conversion into acetate and subsequently favoring the acetoclastic pathway. Similar results were also recently reported by Zhu et al. [47] when adding hydrogen gas into a reactor treating swine manure as substrate. In this case, acetate concentration was also observed along with an initial methane increase from a value of 189 to $245 \mathrm{~L} / \mathrm{kg} \mathrm{VS}$, and a posterior decrease to $210 \mathrm{~L} / \mathrm{kg} \mathrm{VS}$. Methanosaeta accounted for the majority of the methanogens present in this system. These results are in disagreement with those previously reported by Luo and Angelidaki [48], but in this case, the culture was enriched to convert $\mathrm{CO}_{2}$ to $\mathrm{CH}_{4}$ by adding $\mathrm{H}_{2}$ without using any other substrate during this procedure but the $\mathrm{H}_{2} / \mathrm{CO}_{2}$ mixture. The microbial analysis reported by these authors indicated that the dominant species belonged to the order Methanobacteriales, which participate in hydrogenotrophic methanogenesis. Thus, under the continuous addition of hydrogen and biogas, the microflora could treat biogas to obtain a $\mathrm{CH}_{4}$ content of around $95 \%$ at steady state and transform the traditional digestion reactor into a low-cost upgrading system for producing biomethane.

In the case of bioaugmentation as an alternative for favoring the performance of methanogens, Ács et al. [49] evaluated the inoculation of Enterobacter cloacae cells, reporting an overall increase in the gas production rate. The control reactor had a biogas yield of $595 \mathrm{~L} / \mathrm{kg}$ TS, and the one inoculated with extra E. cloacae attained a yield of $718.5 \mathrm{~L} / \mathrm{kg}$ TS after operating for 6 weeks, using continuously stirred reactors in fed-batch mode. A similar evaluation was previously carried out by Kovács et al. [50] also inoculating E. cloacae in a mesophilic system and Caldicellulosiruptor saccharolyticus for the thermophilic reactor. Inoculation gave good results for a short limited time, but the inoculated microflora was washed out and incapable of competing with the microbial consortium. Changes in the loading rate were necessary for allowing the inoculated microorganisms to survive, hence the great relevance between the reactor operating parameters and microbial dominance.

Anaerobic systems may present a high evolution of sulfur compounds negatively affecting performance. Sulfur levels may be high in biogas if the presence of this element is a relevant component of the feed, favoring the growth of sulfate-reducing bacteria (SRB) that are capable of outcompeting acetogens and methanogenic archaea [51]. Large-scale digesters need to deal with the substrate available based on the location of the plant, seasonality, and agro-industrial activity in the plant vicinity. Thus, selecting the proper feeding mixture is not always possible and operational alternatives have been developed to deal with the excessive growth of SRB.

Co-digestion with other residues may help attain a suitable balance of nutrients and equilibrate sulfur and nitrogen levels in the reactor. Manures are characterized by a low carbon-nitrogen $(\mathrm{C} / \mathrm{N})$ ratio; thus, when treated under anaerobic digestion, the excessive levels of ammonia inside the reactor may cause an inhibition of methanogens. Values in the range of 2.7-3.1 $\mathrm{g} / \mathrm{L}$ of ammonia nitrogen can be tolerated by the microflora depending on the inoculum origin and if proper adaptation has been allowed [52-54], whereas values as high as $4.0 \mathrm{~g} / \mathrm{L}$ cause an inhibitory effect on methane production [31,35] but exert a beneficial effect on the tolerance of VFA, which is not observed in systems with low ammonia content [55]. The effect of ammonia in anaerobic digestion systems was deeply reviewed by Yenigün and Demirel [56], explaining the complexity between ammonium concentration, $\mathrm{pH}$, temperature, and acclimation of the microflora. 
Ammonium is a key compound in the buffer capacity of the digester along with bicarbonate and VFAs, thus favoring digestion stability and preventing process imbalances [57]. The performance of ammonia-tolerant anaerobic microflora was reported recently by Gao et al. [58] when evaluating the methane-specific production of this culture using food wastes as substrate. These authors reported $36 \%$ more methane production based on the greater capacity of the culture to assimilate acetate. The equilibrium associated with $\mathrm{NH}_{3} / \mathrm{NH}_{4}{ }^{+}, \mathrm{CO}_{2} / \mathrm{H}_{2} \mathrm{CO}_{3} / \mathrm{HCO}_{3}{ }^{-}$, and $\mathrm{C}_{\mathrm{x}} \mathrm{H}_{\mathrm{y}} \mathrm{COOH} / \mathrm{C}_{\mathrm{x}} \mathrm{H}_{\mathrm{y}} \mathrm{COO}^{-}$favored VFAs and ammonia ionization, reducing the content of free forms of these compounds, attenuating $\mathrm{pH}$ variations, and making the process more robust to fluctuations [57].

Acclimation of the anaerobic microflora allows digestion to proceed under extreme ammonia levels, as demonstrated by Yan et al. [59], who reported the treatment of the OFMSW at an ammonia content of $9.5 \mathrm{~g} / \mathrm{L}$. Bioaugmentation with a pure culture of Methanoculleus bourgensis allowed digestion to proceed at $13.5 \mathrm{~g} \mathrm{NH}_{4}{ }^{+} / \mathrm{L}$ [60]. The experiences regarding digestion performance under such severe conditions seem extremely interesting as academy activity. Still, an extrapolation of these results into industrial scale may find several difficulties that need to be overcome, probably making this solution less attractive. However, an interesting approach would be applying these findings for operating anaerobic reactors under high-solid concentration (or solid-phase reactors) along with thermophilic conditions. Under such circumstances, high ammonia levels should be expected due to the lower volume of the liquid phase and the higher degradation rate of thermophilic processes. The use of acclimated microflora to extreme environments increases biogas yield under such inhibitory conditions, leading to better stabilization of the digested material. This would result in positive outcomes regarding energy production and characteristics of the organic material, thus facilitating nutrient recycling.

\section{Co-Digestion Proposed as the Best Way to Take Advantage of Process Synergies}

Co-digestion is an efficient way for increasing the productivity of the reactor and enhancing biogas yields. The main advantages are the supply of additional nutrients thanks to the presence of co-substrates, equilibrating the feeding mixture. This strategy allows better use of equipment and cost-sharing because multiple waste streams can be processed in a single facility [61]. The treatment of sewage sludge, the OFMSW, waste derived from the agricultural sector-livestock farm wastes and agricultural wastes and energy cropsare the main areas where digestion finds application for producing a significant amount of biogas. The productivity of existing biogas plants may be increased by supplementing different types of materials from other industrial sectors. The economic feasibility of these installations is highly related to the scale and the selling price of products: electricity, heat, and digestate final use. A great number of large-scale digesters have been installed providing economic and environmental advantages [62]. Although some modifications in existing facilities may be necessary in many cases, the combined digestion of different wastes found in the vicinity of many wastewater treatment plants can be a solution for reducing the operating costs and increasing the share of biofuels and renewable energy produced at a specific location.

There are many research documents in the literature regarding successful digestion performance under laboratory scales when treating sewage sludge [34,63] and manures $[32,64]$. Reports regarding large-scale co-digestion are also available, but the number of full-scale studies (particularly the ones with operational issues) evaluating co-digestion with sewage sludge at WWTPs is still very limited. Operating problems are usually related to the characteristics of waste materials, which are highly variable in composition, setting many operational constraints when attempting full-scale implementation [65]. Changes are necessary for the technical routines, maintenance, and installation of new equipment to deal with these materials. Nevertheless, the potential benefits of co-digestion are undeniable, and wastewater treatment facilities can obtain cost savings from introducing wastes into digesters that are treating sewage sludge. These benefits are mainly associated with lower 
energy costs derived from the higher capacity of power production thanks to higher biogas yields [66].

Bolzonella et al. [67] described experiences at Viareggio and Treviso WWTPs (Italy). In this location, source-sorted OFMSW was added as a co-substrate to the reactor treating sewage sludge, obtaining a biogas increment from $3500 \mathrm{~m}^{3} /$ month up to $17,500 \mathrm{~m}^{3} /$ month. A short essay of 2 months was reported by Park et al. [68] at the Lansdowne WWTP from the municipality of Prince George, British Columbia, Canada. Source-sorted food wastes from supermarkets were added as co-substrates. These authors reported an $8-10 \%$ increase in average daily biogas production, but the operation was affected by the clogging of the hose that connected the chopper pump and the sludge recirculation line, which was usually plugged by food wastes, needing to be manually cleared. The authors also described the accumulation of fibrous scum that accumulated near the digester floating roof. The operators indicated the visual presence of impurities in biosolids, thus affecting its quality if land application is the final disposal option.

Masłon et al. [69] reported the performance of co-digestion at the WWTP located in Iława (Poland) for a two-year period using as co-substrate poultry fat wastes. These authors observed an increase in biogas production of $82 \%$ with an enhancement of $29 \%$ in volatile solid removal. Operational constraints may indeed limit the application of co-digestion in these types of units. Still, if successfully overcome, then this treatment option represents an optimum way for recovering the energy potential of many wastes. The addition of crop wastes, maize silage, or carbohydrate-rich substrates greatly enhances biogas production and reactor productivity thanks to the greater amount of readily degradable substrate introduced in the reactor but also to the better performance of the anaerobic biomass.

Table 2 presents a list of different biogas yields found in the literature and values obtained under different reactor operating conditions. Synergies in digestion performance are associated with an adequate balance of nutrients and decreased concentration of inhibitory compounds when digesting the mixture. If this is not the case, the increase experienced in biogas is associated with an additive effect based on the additional organic load supplied. This effect was reported by Søndergaard et al. [70] when evaluating the digestion of single agricultural by-products and their co-digestion with manures. Similar results were also observed by Cuetos et al. [32], studying the co-digestion of swine manure with crop residues (maize, sunflower, rapeseed). These authors also described increments in biogas production when performing biochemical methane potential (BMP) tests, but synergistic effects were not observable. On the contrary, when evaluating reactors under semi-continuous operation, an accumulation of cellulosic biomass took place in the reactor, leading to increased biogas production for some periods because of the degradation of accumulated material. Li et al. [71] reported an enhancement in volatile solid removal when evaluating sewage sludge and food wastes leachate derived from municipal solid wastes incineration plants. In their study, the greater biogas yield was not only attributable to the increment in organic loading rate but also to the higher degradation of solids. 
Table 2. Methane yields reported in the literature under different conditions: Batch digestion, co-digestion, and continuous digestion tests.

\begin{tabular}{|c|c|c|c|}
\hline Digestion Test & OLR (g VS/L d) & $\mathrm{mL} \mathrm{CH}_{4} / \mathrm{g}$ VS & Reference \\
\hline \multicolumn{4}{|l|}{ Batch digestion } \\
\hline \multirow[t]{4}{*}{ Sewage sludge (SS) } & & $248.7 \pm 4.13$ & [72] \\
\hline & & 198.3 & [73] \\
\hline & & $130.46 \pm 8.09$ & {$[74]$} \\
\hline & & 287 & [75] \\
\hline \multirow[t]{3}{*}{ Food wastes (FW) } & & $491.0 \pm 8.79$ & [72] \\
\hline & & 475 & [75] \\
\hline & & $326-497^{1}$ & [29] \\
\hline OFMSW & & 236 & [76] \\
\hline Meadow grass & & $388 \pm 30$ & [70] \\
\hline \multirow[t]{3}{*}{ Cattle manure (CM) } & & 439 & [73] \\
\hline & & 230 & [77] \\
\hline & & $160^{1}$ & [77] \\
\hline Chicken manure & & $520 \pm 130$ & [78] \\
\hline \multirow{2}{*}{ Swine manure (SM) } & & $298.7 \pm 19.7$ & [79] \\
\hline & & $202.0 \pm 14.2$ & [80] \\
\hline glycerin & & $561.3 \pm 55.3$ & [80] \\
\hline \multicolumn{4}{|l|}{ Batch co-digestion } \\
\hline $\mathrm{SS}+\mathrm{FW}$ & & $293-365$ & {$[72]$} \\
\hline WAS $^{2}+$ OFMSW & & $162-243$ & [81] \\
\hline $\mathrm{SS}+$ sludge from brewery & & $176-263$ & [82] \\
\hline $\mathrm{SS}+\mathrm{FW}$ leachate & & $233-344$ & [82] \\
\hline SS + Maize straw & & $336-472.3$ & [73] \\
\hline $\mathrm{SS}+\mathrm{CM}$ & & $352.3-470.3$ & [73] \\
\hline $\mathrm{CM}+$ maize straw & & $534.8-603.5$ & [73] \\
\hline $\mathrm{SM}+$ glycerin & & $349-467$ & [80] \\
\hline Pig manure+ ESBP ${ }^{3}$ & & $212.4^{1}$ & [30] \\
\hline \multicolumn{4}{|l|}{ Continuous operation } \\
\hline \multirow[t]{2}{*}{ SS } & 1.1 & $340.3 \pm 90^{4}$ & [33] \\
\hline & 3.17 & $327^{1}$ & [83] \\
\hline $\mathrm{SM}+$ glycerin & $2-2.9$ & $336-423$ & [84] \\
\hline OFMSW + primary sludge & $4-5$ & $375-404$ & [85] \\
\hline Chicken manure & 3.5 & $53-75.4$ & [86] \\
\hline Chicken manure + dairy cow manure & $3.7-4.7^{5}$ & $350 \pm 110$ & [78] \\
\hline \multicolumn{4}{|l|}{ Solid-phase digestion } \\
\hline Poultry manure & & 24.6 & [87] \\
\hline SS + Poultry manure & & 56.5 & [87] \\
\hline Chicken manure & $11.5^{6}$ & $52.2^{4}$ & [86] \\
\hline Sheep manure & & 184 & [88] \\
\hline Sheep manure + potato peels & & $323-329$ & [88] \\
\hline Pennisetum hybrid & & 78.5 & [89] \\
\hline Horse dung & & 170 & [90] \\
\hline
\end{tabular}

${ }^{1}$ Thermophilic conditions; ${ }^{2}$ WAS: Waste-activated sludge; ${ }^{3}$ ESBP: exhausted sugar beet pulp at 25:75 mixture ratio; ${ }^{4}$ Calculated from data provided in manuscript; ${ }^{5}$ High solid digestion; ${ }^{6}$ Continuous operation.

Residual glycerine is a by-product obtained from the conventional chemical production of biodiesel. With the increase in biodiesel demand worldwide, several industrial plants have flourished to convert vegetable oils and recycled vegetable oils into methylesters. However, crude glycerol formed as the main by-product from the transesterification reaction contains impurities that restrict the direct application of this organic liquid in different industrial processes [91]. The use of crude glycerol has been proposed to boost biogas production. Successful co-digestion with sewage sludge, manures, and leachates has been reported indicating increments in methane yields that can double this parameter when compared with the control [31,91-94]. However, the excessive addition of this co-substrate 
can cause inhibition, which is associated with long-chain fatty acid levels in the reactor, or the accumulation of propionic acid as an intermediary from the anaerobic degradation [95]. Stress associated with VFA build-up was also reported by Huber et al. [96] when adding glycerol as co-substrate at a volumetric percentage of $3 \%$ during the digestion of poultry litter. Other authors reported process imbalance due to the presence of sulfate, which causes the competition of SRB with methanogens when operating under semi-continuous conditions. As a result, a significant decrease in methane yield was reported along with an $\mathrm{H}_{2} \mathrm{~S}$ content in biogas of about $7000 \mathrm{ppm}$ when adding glycerine at an $8 \%$ volumetric proportion to the feeding [84]. Another relevant fact to be considered is the fluctuating price of glycerine, which may be in some cases too low to get sufficient revenues for the biodiesel industry but too high for digestion plants to be a suitable co-substrate. González et al. [97] evaluated the co-digestion of glycerine and swine manure, among other scenarios. They reported a negative outcome from the economic analysis associated mainly with transport costs and the price of this feedstock.

Other reports evaluating different mixtures of wastes characterized by significant problems during single anaerobic degradation indicate better performance after the addition of a co-substrate. Zahedi et al. [98] reported enhanced performance when digesting chicken manure, sewage sludge, and wine distillery wastewater, finding optimal conditions for a mixture of 44:44:12 $(w / w / w)$ representing this ratio: the sequence of sewage sludge/wine distillery wastewater/chicken manure. The results reported by Porselvam et al. [36] led to similar conclusions when evaluating the co-digestion of food wastes and intestine wastes from a slaughterhouse. These studies report better performance of the mixture, and difficulties in attaining the single digestion explain these effects. High lipid contents wastes are prone to cause the accumulation of long-chain fatty acids, wine distillery wastes present toxic phenolic compounds, and high levels of ammonia are observed when digesting chicken manures. A similar phenomenon was also reported by Cuetos et al. [99] when studying the co-digestion of poultry blood with maize residues. This organic stream could not be degraded under mono-digestion conditions, but the addition of maize as a co-substrate from 15 to $70 \%$ (percentage indicating VS proportion of maize in the final mixture) reported methane yields from 192.7 to $311.4 \mathrm{mLCH}_{4} / \mathrm{g}$ VS with the increase of maize addition, whereas the value obtained from maize BMP test was $157.1 \mathrm{mLCH}_{4} / \mathrm{g}$ VS

Co-digestion increases reactor productivity by adjusting the solid content and nutrient balance in the feeding material. The installation may serve multiple industrial and agronomic sectors, taking advantage of the different characteristics of substrates. Higher biogas yields, and therefore greater production of bioenergy, can be obtained. Performance can be optimized based on the annual evolution of the industrial activities, and reactor operating conditions may need more flexibility to cope with a great variety of wastes. These flexible digestion plants will also have to be integrated into the energy grid, thus increasing the share of renewables.

\section{Increasing Reactor Productivity by the Increase in Solid Content and Temperature}

Solid-state anaerobic digestion is a technology capable of treating high organic loadings with a small digester volume. Leachate recirculation reactors have demonstrated operation simplicity. This process can work under batch conditions where the material is loaded, and a liquid recirculation stage allows the redistribution of soluble compounds and microorganisms. However, attaining homogeneity and avoiding compaction of the organic bed is not easy. Therefore, a structuring agent is necessary to prevent preferential circulation pathways and acidification in inner reactor zones. This process is greatly influenced by VFA build-up and inhibitory effects due to high ammonia levels in the leachate. Co-digestion in the presence of a structuring agent has been proposed to alleviate the excessive increase of these inhibitory compounds in the liquid phase and avoid preferential pathways for liquid circulation.

The treatment of lignocellulosic biomass by this technology can also be considered as a suitable option, given the inherent advantage of these materials to create a porous 
structure. The frequency of leachate recirculation also has a great impact on the stability of biogas production. Qian et al. [100] reported that leachate recirculation favored hydrolysis and acidogenesis by its inoculating effect and improved mass transfer, but it also created a washing effect when excessive recirculation was applied, leading to a fast VFA accumulation. Xing et al. [89] also reported a detriment in reactor performance when increasing the recirculation frequency of a solid phase reactor treating lignocellulosic biomass (energy crop Pennisetum hybrid). Even if homogenization and biomass wash-out problems are solved, the process still has to deal with the operating conditions. Batch operation mode creates an uneven evolution of biogas, as methane production is high when the digester is freshly loaded, but it gets much lower close to the end of the process when the digester needs to be reloaded [101]. Operating under staggered mode with biogas storage is a way for attenuating this non-uniform production of biogas. Still, scale factors and higher installation costs may limit the applicability of these measurements.

Ammonia inhibitory conditions can be easily attained in high-solid anaerobic digestion (HSAD) due to the lower dilution capacity of the system. Pastor-Poquet et al. [76] reported $40 \%$ less methane yield when digesting OFMSW at $\mathrm{NH}_{3}$ concentration greater than $2.3 \mathrm{~g} \mathrm{~N}-\mathrm{NH}_{3} / \mathrm{kg}$ and operating at a TS content of $15.0 \%$. The addition of beech sawdust to increase solid content without affecting nutrient ratio decreased localized nitrogen levels. Thus, the risk of acidification was only observed at total solids $\geq 20.0 \%$. Therefore, these authors demonstrated the relationship between the biodegradability of the substrate, operational conditions (TS content), and inoculum-to-substrate ratio, which determines the success of methanogenesis based on the risk of ammonia inhibition and VFA accumulation.

Adsorbents and carbon conductive materials have been evaluated with success to decrease the impact of high inhibitory levels. These strategies may aid in improving the performance of high-solid digestion and solid-phase reactors, given the high tendency of accumulating an excessive amount of inhibitors because of the lower volume of the diluting agent. Petracchini et al. [102] reported the performance of HSAD of food waste and cow manure when adding natural zeolite to the reactor, obtaining biogas yields of $680-920 \mathrm{~mL} / \mathrm{g}$ VS. Adsorbents have the capacity of reducing inhibitory levels of ammonia and total VFA concentration, thus allowing stable digestion to proceed [103,104]. Cuetos et al. [105] demonstrated this better performance when evaluating the digestion of poultry blood. Successful digestion was attained thanks to the addition of activated carbon, indicating that adsorption was involved, but other mechanisms also favor the process, as it was a protecting effect regarding mass transfer limitations. Lower levels of inhibitory compounds are experienced by the microflora attached to the protective sites. These authors reported the growth of microorganisms on the carbon surface and proposed the direct interspecies electron transfer (DIET) mechanism as a phenomenon behind the greater capacity of the system to degrade short-chain fatty acids of the type C3-C5 and iso-forms.

Other management options based on this principle have proven useful in achieving the full degradation of complex organic compounds, as it is the addition of biochar or the presence of bioanodes that favor different degradation pathways [106-108]. Cui et al. [109] demonstrated the successful performance of the HSAD reactor when adding biochar, indicating that the improvement was mainly due to the presence of biochar in the media. This material could enhance food waste hydrolysis by promoting butyric acid degradation thanks to changes in community structures. These authors demonstrated the existence of biochar-mediated DIET by the relation established between the Syntrophomonas and Methanosarcina species. The effect of microbial electrolysis was also evaluated by Liu et al. [110] when digesting sewage sludge using an anaerobic reactor containing an anode brush and a cathode separated by $1 \mathrm{~cm}$. These authors reported a three times increase in the methane production rate. This increment was explained by the electron contribution from the microbial electrolysis system. Moreno et al. [111] also described increments in VFA degradation due to the presence of soft carbon felt electrodes, evidencing the beneficial effect of conductive materials. 
Increasing the temperature to thermophilic regimen has been implemented to improve the treatment capacity and reactor productivity. Under thermophilic conditions, higher degradation rates are attained, achieving greater capacity for treating organics and directly affecting reactor size. When considering reactors under operation, this feature translates into a significant increase in treatment capacity. The biogas yield for mesophilic and thermophilic systems has been reported to be similar, but the real gain is the lower retention time needed for the total degradation of the material $[112,113]$. However, concerns are raised about the quality of digestate regarding dewaterability performance, the organic content of centrates derived from dewatering operations, and levels of labile components in this stream. It is difficult to extract exact comparisons from different studies, but the review performed by Gebreeyessus and Jenicek [114] indicated a preference for the mesophilic system because of the lower stability issues associated with this technology.

Nielsen and Petersen [115] describe the experience of thermophilic digesters $\left(50-55^{\circ} \mathrm{C}\right)$ in operation in Denmark. The process performed at this temperature demonstrated stability, high solid reduction, and pathogen removal. The authors also indicated that the dewatered digested sludge attained a solid content of about $30-40 \%$. However, the major drawback found was the higher demand for polymer in sludge dewatering. De Vrieze et al. [116] reported the transitioning to thermophilic conditions in three WWTPs in Tilburg-Noord, Land van Cuijk, and Bath, located in the Netherlands. These authors indicated an increase in $17.9 \%$ in methane production with the change to thermophilic conditions. Conversely, an increase in nutrient content (nitrogen and phosphorous) of digestate was also observed, affecting the quality of digestate reject water.

Higher VFA and ammonia concentration are usually reported when comparing performance under thermophilic and mesophilic conditions [117-119]. Regarding the organic characteristics of digestates, results are contradictory. Gómez et al. [120] reported greater stabilization of the mesophilic digestate when studying cattle manure digestion. On the other hand, the study of Provenzano et al. [121] indicated greater complexity of the thermophilic digestate derived from sewage sludge and municipal solid waste, which was interpreted as a greater extent of degradation obtained under thermophilic regimen. The chemical characteristics of substrates may explain these differences. Cattle manure has high nitrogen content, leading to higher ammonia release. If it is added that thermophilic conditions also increase the release of this compound, then inhibitory conditions are generated, leading to a lower degradation and quality of digestate. Yenigün and Demirel [56] reviewed the effect of ammonia under mesophilic and thermophilic conditions using data from different essays available in the literature. These authors indicated that discrepancies in results might be associated with free ammonia values reached in the reactor when evaluating different temperature regimens. Therefore, thermophilic systems present higher free ammonia values due to higher temperatures, $\mathrm{pH}$, and an increased degradation rate. The effect of ammonia in these systems may be initially interpreted as having greater susceptibility to this type of inhibitory compound, but in fact, higher free ammonia levels were responsible for the negative effect observed. Thus, adaptation is crucial to guarantee safe operation at either temperature selected.

Takashima and Yaguchi [83] studied HSAD under thermophilic conditions, evaluating the digestion of sewage sludge and reporting successful operation after implementing an ammonia stripping stage applied to the digested sludge. The process also included the return of digestate back to the reactor. This stage allowed keeping TAN at $1720 \mathrm{mg} \mathrm{N} / \mathrm{L}$ (below the $2500 \mathrm{mg} \mathrm{N} / \mathrm{L}$, a value reported as inhibitory in this study), making it possible for the reactor to work at an influent concentration of $9-10 \%$ total solids. The increase in temperature may lead to better process performance when an adequate adaptation of anaerobic microflora is provided. The addition of compounds as carbon conductive materials, adsorbents, or the introduction of bio-electrodes in the digestion systems may seem suitable alternatives for operating high solid reactors and solid-phase digestion at thermophilic regimens. This will increase productivity and reduce reactor size, which dramatically affects capital investment costs and plant economic feasibility. Wang et al. [122] demonstrated 
the greater capacity of thermophilic systems for operating at higher organic loading rates when biochar was added to the reactor, thanks to the improvement in VFA degradation. The use of biogas as an energy vector, biofuel, or raw material for the synthesis of a wide variety of compounds is expected to play a crucial role in the near future regarding the decarbonization of the economy and leading to a better reuse of materials. However, to attain this goal, increased biogas productivity is needed along with a significant reduction in capital investment of installations and operating costs. Expanding the treatment capacity of these plants and achieving a high degree of stabilization are essential. Land application of digestate is a way of attaining the return of nutrients to the production cycles. Any detriment in digestion performance will negatively affect bioenergy production but also digestate characteristics. Thus, the process should be considered as a delicate cycle where all gears should be perfectly integrated.

\section{Biogas and Its Role as Renewable Fuel in the Decarbonization of the Economy}

The valorization of biogas for producing energy or transforming this gas to enrich its methane content implies the application of different technologies for removing impurities and increasing its quality. Figure 2 presents alternatives to produce heat and electricity or to upgrade to attain characteristics similar to natural gas.

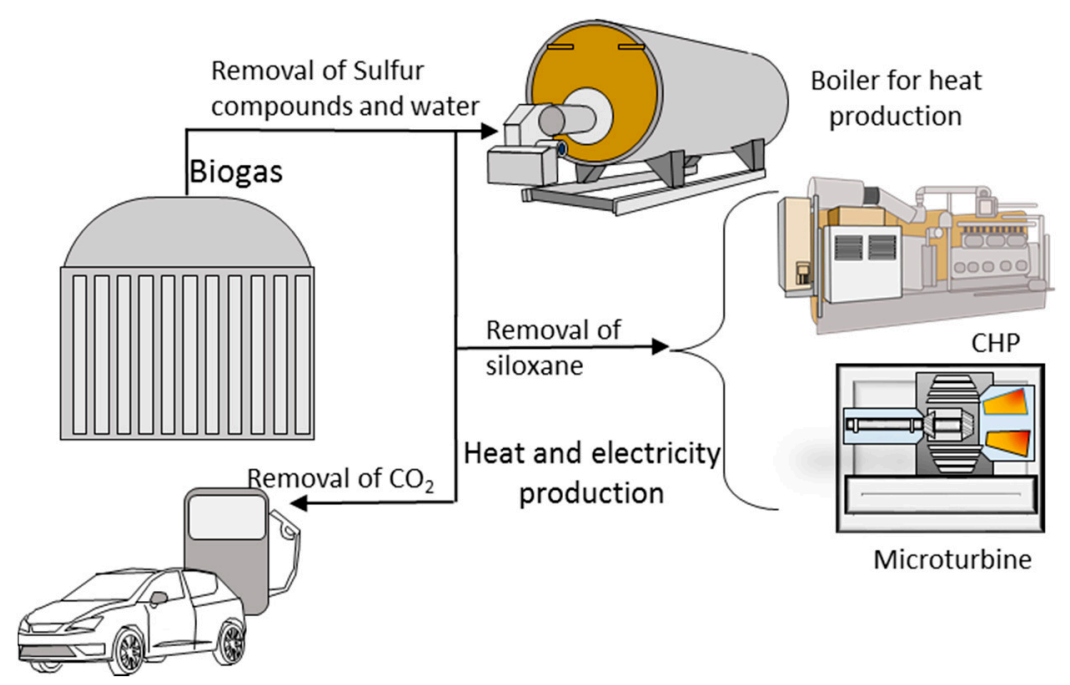

Figure 2. Different technologies for biogas valorization: Heat and electricity production or upgrading to be used as biofuel or injected into the natural gas grid.

Biogas comprises $\mathrm{CH}_{4}$ and $\mathrm{CO}_{2}$ and traces of some other species such as ammonia, sulfidic acid, and mercaptans. Oxygen and nitrogen may also be present [123,124]. Biogas is usually valorized for thermal energy production in boilers or combined heat and power (CHP) units for producing electricity and thermal energy. Upgrading this gas is necessary to remove trace elements such as water vapor, ammonia, small amounts of $\mathrm{O}_{2}, \mathrm{~N}_{2}$, and sulfur compounds. Depending on the type of facility, other compounds may also appear in the gas stream. It is the case of siloxanes representing significant operational problems associated with corrosion and microcrystalline deposits in engines [125]. The complexity of the upgrading systems depends on the final use intended for this gas. The direct use for electricity and heat production implies removing the most problematic components to reduce corrosion and abrasion problems. If biogas is intended to be used as biofuel or upgraded to be compatible with the natural gas grid, then removing carbon dioxide is imperative. Different technologies are commercially available for increasing biogas quality, such as water scrubbing, physical removal of compounds by adsorption/absorption processes, pressure swing adsorption, chemical absorption, membrane separation, and cryogenic and biological technologies dedicated to the fixation of $\mathrm{CO}_{2}$ [126-128]. 
The addition of iron salts has been a traditional method for the precipitation of iron sulfur, such as the use of iron (III) and iron (II) chloride $[129,130]$, and specific iron hydroxide formulations, such as BC.ATOX scon and liquid from Schaumann Bioenergy (Pinneberg, Germany) [131,132]. Gas desulfurization is also carried out using iron hydroxides [133], as it is the use of FerroSorp ${ }^{\circledR}$ (Interra Global Corp, Park Ridge, IL, USA) [134] and ferrous sulfates and chloride solutions from Kronos ecohem ${ }^{\circledR}$ (Kronos International, Inc., Leverkusen, Germany) [135]. Other technologies consider the treatment of biogas using biological processes [136], or adsorption using activated carbon filters.

Micro-aeration is another efficient and low-cost way for reducing hydrogen sulfide in biogas. Small amounts of air (oxygen) are introduced into the digester. Sulfide is oxidized into elemental sulfur $\left(S^{\circ}\right)$ by sulfide-oxidizing bacteria. This process can be carried out on the head of the digester, or small amounts of air can also be injected with biogas recirculation into the reactor liquid phase [137]. The co-existence of sulfate-oxidizing bacteria (SOB) and SRB occurs in bioreactors, where SRB reduces $\mathrm{SO}_{4}{ }^{2-}$ to sulfide and SOB oxidizes this latter compound into $\mathrm{S}^{\circ}$ and/or $\mathrm{SO}_{4}{ }^{2-}$. The addition of oxygen for sulfide removal can be calculated using the molar ratio of $\mathrm{O}_{2} / \mathrm{S}^{2-}$ from the stoichiometry; therefore, $0.5 \mathrm{~mol} \mathrm{O}_{2} / \mathrm{mol} \mathrm{S}^{2-}$ is required for $\mathrm{H}_{2} \mathrm{~S}$ to be reacted into $\mathrm{S}^{\circ}$ [138]. However, the addition of small amounts of air into the system brings, as a consequence, the increase of nitrogen levels in biogas, thus reducing its quality if it is upgraded to biomethane. Scrubbers using water or organics solvents as absorption media can remove $\mathrm{CO}_{2}$ and trace components from biogas but not oxygen and nitrogen. Pressure swing adsorption is another technology widely applied for upgrading biogas, but complex adsorbent bed configurations are needed if both nitrogen and oxygen are to be removed, thus increasing costs [139].

Biogas has a great potential to be used as biofuel with possibilities in complementing natural gas fuel stations to guarantee a share in renewables. However, the current biofuel market is dominated by bio-ethanol and biodiesel. The first one derived from the fermentation of sugars, needing a great energy demand for separating the alcohol from the broth, and the second not being exempt from debate due to the origin of vegetable oils. The use of lignocellulosic biomass for producing ethanol (second-generation ethanol) is an alternative for increasing the availability of materials dedicated to biofuel production, but it also implies the application of pre-treatments, increasing the demand for energy and the formation of undesirable compounds that inhibit the fermentation [140]. Biogas is easily separated from the biological reactor because it forms a differentiated gas phase. This gas can be either used as an exclusive fuel or as a supplement to reduce particulate and NOx emissions in compression ignition engines. Several gas-diesel mixtures have been studied to evaluate this performance under different engine speeds [141-143], reporting promising results regarding lower particulate emissions.

Other promising processes for biofuel production are thermal technologies, including pyrolysis, gasification, and wet oxidation, but the current development and installation costs of these technologies have restrained an extended implementation of these alternatives. However, future restrictions in the use of fossil fuels and improvement in technology developments may lead to the transformation of current waste treatment centers. The integration of different units would allow a complete valorization of resources. This may be the case of integrating digestion and thermal processes, which recently has been subject to extensive research [144-146] since the thermal valorization of digested material increases the recovery of energy and valuable products $[147,148]$. Char obtained from pyrolysis may serve as an adsorbent agent in biogas upgrading $[149,150]$, thus reducing operational costs.

The size of the installation and the treatment capacity dictate the selection of the best alternatives for biogas upgrading, having a major effect on the final unitary cost. In the case of the Spanish government, a minimum content of about $90 \%$ methane is established in the upgraded biogas, with a $\mathrm{CO}_{2}$ content no greater than $2 \%$ [151]. The Spanish grid for natural gas transport is divided into the primary grid with a pressure greater than 60 bar and a secondary grid composed of gas pipelines with a pressure range between 16 and 
60 bars [152]. This implies that a substantial amount of energy for compressing biogas is needed if the transport grid selected is the primary grid system. Thus, the use of upgraded biogas in different economic sectors is preferable to be associated with the lower pressure grid to avoid stringent requirements in cleaning and compressing biogas.

Anaerobic digestion should be one of the relevant technologies for reaching the objectives of circular economy, considering the capacity for producing methane and reducing the volume of waste organics. However, the aim of making biogas a major component of the energy mix market is still far from being a reality. The number of new installations keeps a different rate in European countries. The main reason behind this is the high costs of these facilities and low revenues, which are linked to government subsidies in many countries. The economy of scale favors large plants, but social rejection may also increase with the greater size of the installation. This phenomenon is usually associated with the transport of a significant amount of wastes, and the plant may cause the "Not In My Back Yard" syndrome during its construction and operation, which may appear if residents worry about the negative impacts on the health and environment [153].

The Spanish scenario presents an evolution in biogas technology that may be cataloged as upsetting, having a low share in the Spanish energy mix. The production of electricity from renewables is dominated by hydraulic and wind power, having a share of $19.4 \%$ and $22.6 \%$, respectively, when the global electricity production is considered. Regarding electricity production just from renewable sources, hydraulic energy represents $34 \%$, and wind represents $48 \%$. Biogas has a scarce presence of $1.0 \%$, which denotes the poor participation of anaerobic digestion in the Spanish electricity production sector. This feature is also observed if primary energy consumption from renewables is analyzed [154]. This illustrates the problems suffered by this technology when industrial implementation for treating different types of waste is intended. The main production of biogas in Spain is derived from WWTP digesters and landfills [155]. The attempts of increasing the number of installations for valorizing livestock farm wastes and agro-industrial wastes have failed due to a great diversity of factors. Still, the main ones are associated with the profitability of the plant, excessively high capital investment, and governmental subsidies not fully adequate to the Spanish scenario.

Increasing reactor productivity, reducing capital investment and operating costs may help attain a higher share of this technology in the energy sector. If this technology is desired to play a relevant role in decarbonizing the economy, great efforts are needed regarding a favorable policy regulation capable of promoting a significant increase in the number of new installations of highly efficient digestion systems. The different technologies available for increasing biogas yields include pre-treatments to facilitate the hydrolysis of particulate material to allow easy access to anaerobic microflora. However, some technologies may increase the facility's energy demand and negatively affect installation costs [156]. The thermal hydrolysis process is fully developed at the industrial level and allows the enhancement in biogas production along with a significant decrease in the volume of sludge [157]. This process also reduces the time needed for digestion, which is particularly true when specific methodologies such as recuperative thickening are implemented, allowing for at least a 100\% increase in the throughput rates of the anaerobic reactor [158].

Thermal pre-treatment is widely applied due to its capacity for recovering thermal energy. Nonetheless, the energy balance of the plant in some cases may be affected due to the additional equipment necessary for installing the process itself, causing in some cases that the expected increase in biogas production does not offset the higher demand for energy of the global process [159]. Other commercially available pre-treatment techniques are ultrasonication (Hielscher Ultrasonics $\mathrm{GmbH}$, Teltow, Germany) [160], electrokinetic disintegration (BioCrack from Vogelsang GmbH, Essen, Germany) [161], and high-pressure homogenization such as the Crown ${ }^{\mathrm{TM}}$ Disintegration System by Evoqua Water Technologies (Pittsburgh, PA, USA) [162]. There are several other chemical, mechanical, and biological processes subject to extensive research, which have been reviewed by Wang et al. [163], 
Zhen et al. [164], Wacławek et al. [165], and Nguyen et al. [166], showing successful results regarding improvement in biogas yields.

When comparing the conventional digestion process under mesophilic conditions, the retention time of sewage sludge digester is usually about 20-30 days and about 40-60 days when manures and farm wastes are considered. The increase in temperature of the process to operate under a thermophilic regimen may reduce retention time thanks to the greater degradation rate of this process [116]. A similar output is expected when a pre-treatment operation is introduced in the global process, reducing greatly the volume of the digester, if compared with the conventional mesophilic process. Therefore, there is a wide range for optimizing digestion performance when implemented at large-scale. Figure 3 represents a schematization of the process treating a hypothetical waste with an assumed biogas yield of $325 \mathrm{~mL} \mathrm{CH}_{4} / \mathrm{g}$ VS. For an installation with a treatment capacity of 30,000 $\mathrm{t} /$ year, the productivity of the reactor may be increased from 0.22 to $2.92 \mathrm{~m}^{3} \mathrm{CH}_{4} / \mathrm{m}_{\mathrm{r}}{ }^{3} \mathrm{~d}$ if fermentation takes place under high solid concentration conditions, and HRT can be reduced to one-third of the initial value by increasing the process temperature and pre-treating the feed.

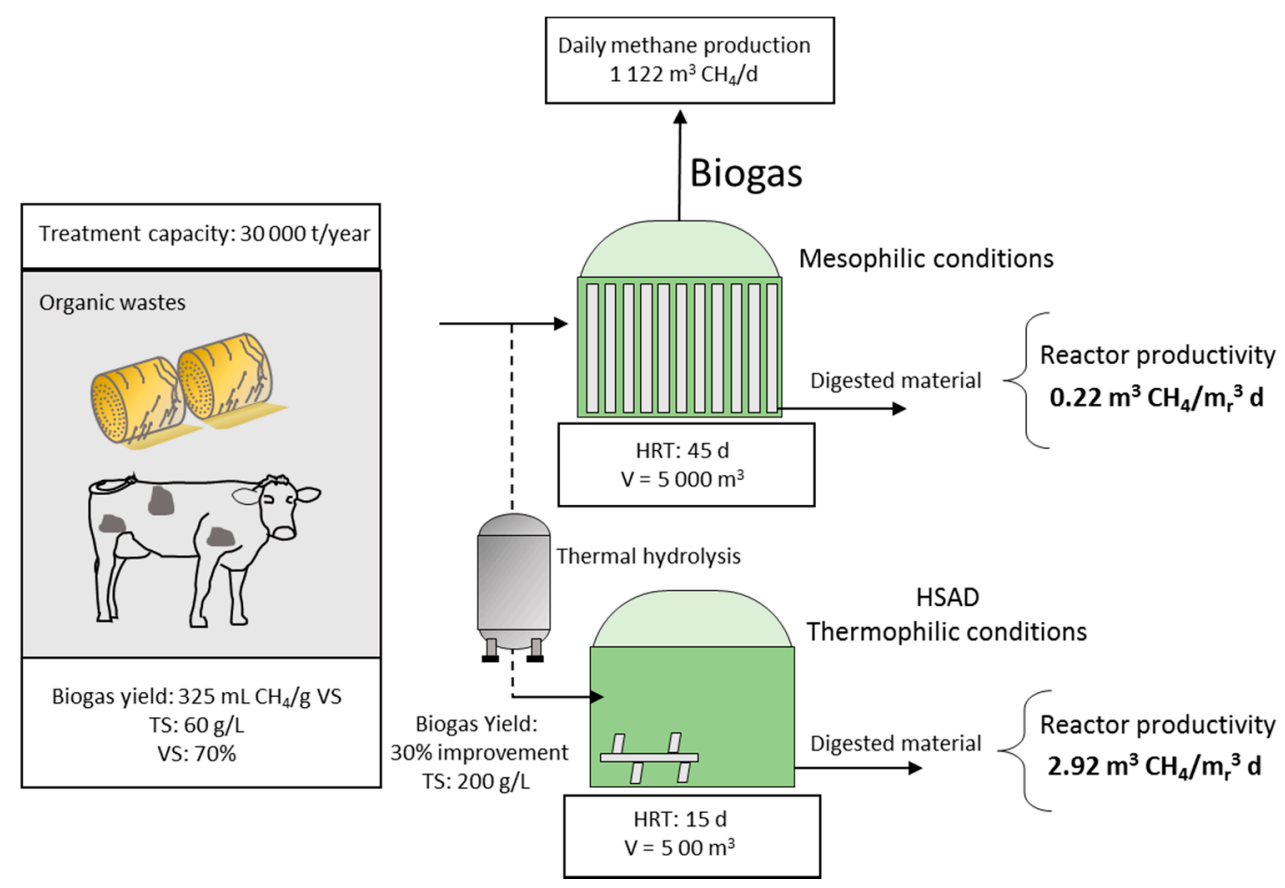

Figure 3. The schematization of reactor productivity increase expected when operating under high solid anaerobic digestion (HSAD) and considering an improvement in biogas yield thanks to the application of pre-treatments. Negative effects associated with accumulation of VFA and $\mathrm{NH}_{3}$ were disregarded. TS: total solid, VS: percentage of volatile solids, HRT: hydraulic retention time, $\mathrm{V}$ : volume of the reactor, $\mathrm{mr}^{3}$ represents the unit used to measure reactor volume expressed in cubic meters.

Biogas can play a relevant role in decarbonizing the economy if the profitability and productivity of digestion plants are significantly increased. The average installation costs per unit of material treated have been estimated for different authors. These values are around $140-340 € / \mathrm{t}$ year $[167,168]$, considering electricity production by CHP units. Including a biogas upgrading stage increases costs by 5-55€ per unit of biogas flow (expressed as $\mathrm{m}^{3} / \mathrm{h}$, STP) treated, increasing the price with the decrease in scale [128]. Aryal and Kvist [169] indicated that the additional costs of biogas upgrading and compression to make it compatible with the natural gas grid create additional barriers for biogas implementation. Thus, reducing compression stages by supplying biogas directly to large consumers will avoid additional compression costs. If biogas is to be considered a substitute for natural gas or to be used as a supplementary fuel along with natural gas, then upgrading 
is imperative, but this also causes an increment in costs that when summed up to the already high installation costs of this type of facilities makes this mature technology just a promising process that encounters several difficulties in attaining economic feasibility [7]. Great efforts should be placed on developing high rate reactors with an outstanding capacity to operate under solid-phase conditions without experiencing detriments in biogas yields. The great reduction in size and the ability to work at high loading rates may be crucial to increase energy outputs, thus leading to a whole new generation of a highly profitable digestion system that outpaces the need for government subsidies.

\section{Conclusions}

The ability of anaerobic digestion for treating a great variety of wastes and producing bioenergy, and the high industrial development of this technology make it an ideal candidate to be part of different processes. However, there is still an urgent need for increasing the treatment capacity of digestion plants in order to offset the high installation and operating costs. There is a multitude of research lines dealing with alternatives for increasing reactor productivity. The increase in temperature to operate at the thermophilic range and the application of high-solid or solid-phase digestion may seem the most adequate technologies to guarantee a significant reduction in reactor size. However, the accumulation of inhibitory compounds reduces the benefits that could be obtained, needing thus additional measurements to overcome this problem. The addition of adsorbents, carbon conductive materials, or bio-electrodes may seem adequate for temporally removing these components and offering a protective shelter to microbial biomass along with an increased degradation rate of intermediaries by the activation of different microbial routes. The further development of these strategies may help attain lower capital investments and operating costs, thus allowing for digestion to be considered a key process in the new circular economy model.

Research lines should focus on optimizing the different parameters affecting digestion performance to obtain new process configurations capable of outstanding hydrolytic conversions and gas yields when working under high solid conditions. Reactor downsizing and reducing process complexity will favor the production of bioenergy from biogas. The development of a more sustainable economic model should consider a priority the integration of digestion technology in the energy market along with the recycling of nutrients, and different intermediary compounds derived from this process.

Author Contributions: Conceptualization, X.G.; investigation, J.G.-C.; resources, M.E.; data curation, J.G.-C.; writing — original draft preparation, X.G., M.E.; writing—review and editing, X.G.; visualization, J.G.-C.; supervision, X.G. All authors have read and agreed to the published version of the manuscript.

Funding: This research received no external funding.

Institutional Review Board Statement: Not applicable.

Informed Consent Statement: Not applicable.

Data Availability Statement: Data sharing not applicable.

Acknowledgments: Authors wish to thank the support and information regarding plant data availability of Exporinsa.

Conflicts of Interest: The authors declare no conflict of interest.

\section{References}

1. Valero, A.; Valero, A. Thermodynamic rarity and recyclability of raw materials in the energy transition: The need for an in-spiral economy. Entropy 2019, 21, 873. [CrossRef]

2. Gregson, N.; Crang, M.; Fuller, S.; Holmes, H. Interrogating the circular economy: The moral economy of resource recovery in the EU. Econ. Soc. 2015, 44, 218-243. [CrossRef]

3. Korhonen, J.; Honkasalo, A.; Seppälä, J. Circular economy: The concept and its limitations. Ecol. Econ. 2018, 143, 37-46. [CrossRef] 
4. EUR-Lex. Communication from the Commission to the European Parliament, the Council, the European Economic and Social Committee and the Committee of the Regions. Available online: https: / eur-lex.europa.eu/legal-content/EN/TXT/?qid=1583 933814386\&uri=COM:2020:98:FIN (accessed on 21 April 2021).

5. Molina-Moreno, V.; Leyva-Díaz, J.C.; Llorens-Montes, F.J.; Cortés-García, F.J. Design of indicators of circular economy as instruments for the evaluation of sustainability and efficiency in wastewater from pig farming industry. Water 2017, 9, 653. [CrossRef]

6. Kiselev, A.; Magaril, E.; Magaril, R.; Panepinto, D.; Ravina, M.; Zanetti, M.C. Towards Circular Economy: Evaluation of Sewage Sludge Biogas Solutions. Resources 2019, 8, 91. [CrossRef]

7. Sevillano, C.; Pesantes, A.; Carpio, E.P.; Martínez, E.; Gómez, X. Anaerobic Digestion for Producing Renewable Energy-The Evolution of This Technology in a New Uncertain Scenario. Entropy 2021, 23, 145. [CrossRef]

8. Rekleitis, G.; Haralambous, K.-J.; Loizidou, M.; Aravossis, K. Utilization of Agricultural and Livestock Waste in Anaerobic Digestion (A.D): Applying the Biorefinery Concept in a Circular Economy. Energies 2020, 13, 4428. [CrossRef]

9. Tantau, A.D.; Maassen, M.A.; Fratila, L. Models for Analyzing the Dependencies between Indicators for a Circular Economy in the European Union. Sustainability 2018, 10, 2141. [CrossRef]

10. Lee, Y.-R.; Tsai, W.-T. Valorization of Value-Added Resources from the Anaerobic Digestion of Swine-Raising Manure for Circular Economy in Taiwan. Fermentation 2020, 6, 81. [CrossRef]

11. Menon, A.; Lyng, J.G. Circular bioeconomy solutions: Driving anaerobic digestion of waste streams towards production of high value medium chain fatty acids. Rev. Environ. Sci. Bio/Technol. 2021, 20, 189-208. [CrossRef]

12. Pecorini, I.; Peruzzi, E.; Albini, E.; Doni, S.; Macci, C.; Masciandaro, G.; Iannelli, R. Evaluation of MSW Compost and Digestate Mixtures for a Circular Economy Application. Sustainability 2020, 12, 3042. [CrossRef]

13. Selvaggi, R.; Valenti, F. Assessment of Fruit and Vegetable Residues Suitable for Renewable Energy Production: GIS-Based Model for Developing New Frontiers within the Context of Circular Economy. Appl. Syst. Innov. 2021, 4, 10. [CrossRef]

14. Mateescu, C.; Dima, A.-D. Critical analysis of key barriers and challenges to the growth of the biogas sector: A case study for Romania. Biomass Convers. Biorefinery 2020, 1-14. [CrossRef]

15. Roopnarain, A.; Ndaba, B.; Bello-Akinosho, M.; Bamuza-Pemu, E.; Mukhuba, M.; Nkuna, R.; Adeleke, R. Biogas Technology in Africa: An Assessment of Feedstock, Barriers, Socio-Economic Impact and the Way Forward. In Biogas Production; Springer: Cham, Switzerland, 2020; pp. 415-445.

16. Velivela, A.; Barham, H.; Bauer, J.; Roschke, J.; Daim, T.U.; Meissner, D. Biogas: Converting Waste to Energy. In Science, Technology and Innovation Studies; Springer: Cham, Switzerland, 2020; pp. 285-298.

17. Wainaina, S.; Awasthi, M.K.; Sarsaiya, S.; Chen, H.; Singh, E.; Kumar, A.; Ravindran, B.; Awasthi, S.K.; Liu, T.; Duan, Y.; et al. Resource recovery and circular economy from organic solid waste using aerobic and anaerobic digestion technologies. Bioresour. Technol. 2020, 301, 122778. [CrossRef] [PubMed]

18. Diamantis, V.; Eftaxias, A.; Stamatelatou, K.; Noutsopoulos, C.; Vlachokostas, C.; Aivasidis, A. Bioenergy in the era of circular economy: Anaerobic digestion technological solutions to produce biogas from lipid-rich wastes. Renew. Energy 2021, 168, 438-447. [CrossRef]

19. Song, J.; Wang, Y.; Zhang, S.; Song, Y.; Xue, S.; Liu, L.; Lvy, X.; Wang, X.; Yang, G. Coupling biochar with anaerobic digestion in a circular economy perspective: A promising way to promote sustainable energy, environment and agriculture development in China. Renew. Sustain. Energy Rev. 2021, 144, 110973. [CrossRef]

20. Loizia, P.; Neofytou, N.; Zorpas, A.A. The concept of circular economy strategy in food waste management for the optimi-zation of energy production through anaerobic digestion. Environ. Sci. Pollut. Res. 2019, 26, 14766-14773. [CrossRef]

21. Panigrahi, S.; Sharma, H.B.; Dubey, B.K. Integrated Bioprocessing of Urban Organic Wastes by Anaerobic Digestion Coupled with Hydrothermal Carbonization for Value Added Bio-Carbon and Bio-Product Recovery: A Concept of Circular Economy. In Lecture Notes in Civil Engineering; Springer: Cham, Switzerland, 2020; Volume 89, pp. 47-54.

22. Sharma, H.B.; Panigrahi, S.; Sarmah, A.K.; Dubey, B.K. Downstream augmentation of hydrothermal carbonization with anaerobic digestion for integrated biogas and hydrochar production from the organic fraction of municipal solid waste: A circular economy concept. Sci. Total Environ. 2020, 706, 135907. [CrossRef]

23. Paul, S.; Dutta, A.; Defersha, F.; Dubey, B. Municipal Food Waste to Biomethane and Biofertilizer: A Circular Economy Concept. Waste Biomass Valorization 2017, 9, 601-611. [CrossRef]

24. Ribić, B.; Voća, N.; Ilakovac, B. Concept of sustainable waste management in the city of Zagreb: Towards the implementation of circular economy approach. J. Air Waste Manag. Assoc. 2016, 67, 241-259. [CrossRef] [PubMed]

25. Ziganshin, A.M.; Schmidt, T.; Scholwin, F.; Il'Inskaya, O.N.; Harms, H.; Kleinsteuber, S. Bacteria and archaea involved in anaerobic digestion of distillers grains with solubles. Appl. Microbiol. Biotechnol. 2010, 89, 2039-2052. [CrossRef] [PubMed]

26. Langer, S.G.; Gabris, C.; Einfalt, D.; Wemheuer, B.; Kazda, M.; Bengelsdorf, F.R. Different response of bacteria, archaea and fungi to process parameters in nine full-scale anaerobic digesters. Microb. Biotechnol. 2019, 12, 1210-1225. [CrossRef]

27. Van, D.P.; Fujiwara, T.; Leu-Tho, B.; Toan, S.; Phu, P.; Hoang-Minh, G. A review of anaerobic digestion systems for biode-gradable waste: Configurations, operating parameters, and current trends. Environ. Eng. Res. 2019, 25, 1-17. [CrossRef]

28. David, A.; Govil, T.; Tripathi, A.K.; McGeary, J.; Farrar, K.; Sani, R.K. Thermophilic anaerobic digestion: Enhanced and sus-tainable methane production from co-digestion of food and lignocellulosic wastes. Energies 2018, 11, 2058. [CrossRef] 
29. Xue, S.; Zhao, N.; Song, J.; Wang, X. Interactive Effects of Chemical Composition of Food Waste during Anaerobic Co-Digestion under Thermophilic Temperature. Sustainability 2019, 11, 2933. [CrossRef]

30. Gómez-Quiroga, X.; Aboudi, K.; Álvarez-Gallego, C.J.; Romero-García, L.I. Enhancement of methane production in ther-mophilic anaerobic co-digestion of exhausted sugar beet pulp and pig manure. Appl. Sci. 2019, 9, 1791. [CrossRef]

31. Lobato, A.; Cuetos, M.; Gómez, X.; Morán, A. Improvement of biogas production by co-digestion of swine manure and residual glycerine. Biofuels 2010, 1, 59-68. [CrossRef]

32. Cuetos, M.J.; Fernández, C.; Gómez, X.; Moran, A. Anaerobic co-digestion of swine manure with energy crop residues. Biotechnol. Bioprocess Eng. 2011, 16, 1044-1052. [CrossRef]

33. Martínez, E.J.; Sotres, A.; Arenas, C.B.; Blanco, D.; Martínez, O.; Gómez, X. Improving Anaerobic Digestion of Sewage Sludge by Hydrogen Addition: Analysis of Microbial Populations and Process Performance. Energies 2019, 12, 1228. [CrossRef]

34. Edelmann, W.; Engeli, H.; Gradenecker, M. Co-digestion of organic solid waste and sludge from sewage treatment. Water Sci. Technol. 2000, 41, 213-221. [CrossRef]

35. Cuetos, M.J.; Gómez, X.; Otero, M.; Morán, A. Anaerobic digestion of solid slaughterhouse waste (SHW) at laboratory scale: Influence of co-digestion with the organic fraction of municipal solid waste (OFMSW). Biochem. Eng. J. 2008, 40, 99-106. [CrossRef]

36. Porselvam, S.; Mahendra, B.; Srinivasan, S.V.; Ravindranath, E.; Suthanthararajan, R. Enhanced Biogas Production from Codigestion of Intestine Waste from Slaughterhouse and Food Waste. Energy Fuels 2017, 31, 12133-12140. [CrossRef]

37. Lyberatos, G.; Skiadas, I.V. Modelling of anaerobic digestion-A review. Global Nest. Int. J. 1999, 1, 63-76.

38. Demirel, B.; Scherer, P. The roles of acetotrophic and hydrogenotrophic methanogens during anaerobic conversion of biomass to methane: A review. Rev. Environ. Sci. Bio/Technol. 2008, 7, 173-190. [CrossRef]

39. Pavlostathis, S.G.; Giraldo-Gomez, E. Kinetics of Anaerobic Treatment. Water Sci. Technol. 1991, 24, 35-59. [CrossRef]

40. Vavilin, V.; Fernandez, B.; Palatsi, J.; Flotats, X. Hydrolysis kinetics in anaerobic degradation of particulate organic material: An overview. Waste Manag. 2008, 28, 939-951. [CrossRef]

41. González, J.; Sánchez, M.E.; Gómez, X. Enhancing Anaerobic Digestion: The Effect of Carbon Conductive Materials. C 2018, 4, 59. [CrossRef]

42. Christy, P.M.; Gopinath, L.; Divya, D. A review on anaerobic decomposition and enhancement of biogas production through enzymes and microorganisms. Renew. Sustain. Energy Rev. 2014, 34, 167-173. [CrossRef]

43. Whitmore, T.N.; Lloyd, D.; Jones, G.; Williams, T.N. Hydrogen-dependent control of the continuous anaerobic digestion process. Appl. Microbiol. Biotechnol. 1987, 26, 383-388. [CrossRef]

44. Ban, Q.; Li, J.; Zhang, L.; Jha, A.K.; Nies, L. Linking Performance with Microbial Community Characteristics in an Anaerobic Baffled Reactor. Appl. Biochem. Biotechnol. 2013, 169, 1822-1836. [CrossRef]

45. Dubé, C.-D.; Guiot, S.R. Direct Interspecies Electron Transfer in Anaerobic Digestion: A Review. Blue Biotechnol. 2015, 151, 101-115. [CrossRef]

46. Bagi, Z.; Ács, N.; Bálint, B.; Horváth, L.; Dobó, K.; Perei, K.R.; Rákhely, G.; Kovács, K.L. Biotechnological intensification of biogas production. Appl. Microbiol. Biotechnol. 2007, 76, 473-482. [CrossRef]

47. Zhu, X.; Chen, L.; Chen, Y.; Cao, Q.; Liu, X.; Li, D. Effect of H2 addition on the microbial community structure of a mesophilic anaerobic digestion system. Energy 2020, 198, 117368. [CrossRef]

48. Luo, G.; Angelidaki, I. Integrated biogas upgrading and hydrogen utilization in an anaerobic reactor containing enriched hydrogenotrophic methanogenic culture. Biotechnol. Bioeng. 2012, 109, 2729-2736. [CrossRef]

49. Ács, N.; Bagi, Z.; Rákhely, G.; Minárovics, J.; Nagy, K.; Kovács, K.L. Bioaugmentation of biogas production by a hydro-genproducing bacterium. Bioresour. Technol. 2015, 186, 286-293. [CrossRef]

50. Kovács, K.L.; Ács, N.; Kovács, E.; Wirth, R.; Rákhely, G.; Strang, O.; Herbel, Z.; Bagi, Z. Improvement of Biogas Production by Bioaugmentation. BioMed Res. Int. 2012, 2013, 1-7. [CrossRef]

51. Dar, S.A.; Kleerebezem, R.; Stams, A.J.M.; Kuenen, J.G.; Muyzer, G. Competition and coexistence of sulfate-reducing bacteria, acetogens and methanogens in a lab-scale anaerobic bioreactor as affected by changing substrate to sulfate ratio. Appl. Microbiol. Biotechnol. 2008, 78, 1045-1055. [CrossRef] [PubMed]

52. Hobson, P.; Shaw, B. Inhibition of methane production by Methanobacterium formicicum. Water Res. 1976, 10, 849-852. [CrossRef]

53. Braun, R.; Huber, P.; Meyrath, J. Ammonia toxicity in liquid piggery manure digestion. Biotechnol. Lett. 1981, 3, 159-164. [CrossRef]

54. Omil, F.; Méndez, R.; Lema, J.M. Anaerobic treatment of saline wastewaters under high sulphide and ammonia content. Bioresour. Technol. 1995, 54, 269-278. [CrossRef]

55. Procházka, J.; Dolejš, P.; Máca, J.; Dohányos, M. Stability and inhibition of anaerobic processes caused by insufficiency or excess of ammonia nitrogen. Appl. Microbiol. Biotechnol. 2012, 93, 439-447. [CrossRef] [PubMed]

56. Yenigün, O.; Demirel, B. Ammonia inhibition in anaerobic digestion: A review. Process. Biochem. 2013, 48, 901-911. [CrossRef]

57. Molinuevo-Salces, B.; García-González, M.C.; González-Fernández, C.; Cuetos, M.J.; Morán, A.; Gómez, X. Anaerobic co-digestion of livestock wastes with vegetable processing wastes: A statistical analysis. Bioresour. Technol. 2010, 101, 9479-9485. [CrossRef] [PubMed]

58. Gao, S.; Lei, X.; Ruan, W.; Zhao, M. Synergetic enhancement of methane production and system resilience during anaerobic digestion of food waste in ammonia-tolerant anaerobic sludge system. Environ. Sci. Pollut. Res. 2021, 1-11. [CrossRef] 
59. Yan, M.; Fotidis, I.A.; Tian, H.; Khoshnevisan, B.; Treu, L.; Tsapekos, P.; Angelidaki, I. Acclimatization contributes to stable anaerobic digestion of organic fraction of municipal solid waste under extreme ammonia levels: Focusing on microbial community dynamics. Bioresour. Technol. 2019, 286, 121376. [CrossRef] [PubMed]

60. Yan, M.; Treu, L.; Campanaro, S.; Tian, H.; Zhu, X.; Khoshnevisan, B.; Tsapekos, P.; Angelidaki, I.; Fotidis, I.A. Effect of ammonia on anaerobic digestion of municipal solid waste: Inhibitory performance, bioaugmentation and microbiome functional reconstruction. Chem. Eng. J. 2020, 401, 126159. [CrossRef]

61. Alatriste-Mondragón, F.; Samar, P.; Cox, H.H.J.; Ahring, B.K.; Iranpour, R. Anaerobic Codigestion of Municipal, Farm, and Industrial Organic Wastes: A Survey of Recent Literature. Water Environ. Res. 2006, 78, 607-636. [CrossRef]

62. Mata-Alvarez, J.; Dosta, J.; Macé, S.; Astals, S. Codigestion of solid wastes: A review of its uses and perspectives including modeling. Crit. Rev. Biotechnol. 2011,31, 99-111. [CrossRef]

63. Gómez, X.; Cuetos, M.J.; Cara, J.; Moran, A.; García, A.I. Anaerobic co-digestion of primary sludge and the fruit and vegetable fraction of the municipal solid wastes: Conditions for mixing and evaluation of the organic loading rate. Renew. Energ. 2006, 31, 2017-2024. [CrossRef]

64. Babaee, A.; Shayegan, J.; Roshani, A. Anaerobic slurry co-digestion of poultry manure and straw: Effect of organic loading and temperature. J. Environ. Health Sci. Eng. 2013, 11, 15. [CrossRef]

65. Nghiem, L.D.; Koch, K.; Bolzonella, D.; Drewes, J.E. Full scale co-digestion of wastewater sludge and food waste: Bottlenecks and possibilities. Renew. Sustain. Energy Rev. 2017, 72, 354-362. [CrossRef]

66. Chow, W.L.; Chong, S.; Lim, J.W.; Chan, Y.J.; Chong, M.F.; Tiong, T.J.; Chin, J.K.; Pan, G.-T. Anaerobic Co-Digestion of Wastewater Sludge: A Review of Potential Co-Substrates and Operating Factors for Improved Methane Yield. Processes 2020, 8, 39. [CrossRef]

67. Bolzonella, D.; Battistoni, P.; Susini, C.; Cecchi, F. Anaerobic codigestion of waste activated sludge and OFMSW: The experi-ences of Viareggio and Treviso plants (Italy). Water Sci. Technol. 2006, 53, 203-211. [CrossRef] [PubMed]

68. Park, N.D.; Thring, R.W.; Garton, R.P.; Rutherford, M.P.; Helle, S.S. Increased biogas production in a wastewater treatment plant by anaerobic co-digestion of fruit and vegetable waste and sewer sludge-A full scale study. Water Sci. Technol. 2011, 64, 1851-1856. [CrossRef] [PubMed]

69. Masłoń, A.; Czarnota, J.; Szaja, A.; Szulżyk-Cieplak, J.; Łagód, G. The Enhancement of Energy Efficiency in a Wastewater Treatment Plant through Sustainable Biogas Use: Case Study from Poland. Energies 2020, 13, 6056. [CrossRef]

70. Søndergaard, M.M.; Fotidis, I.A.; Kovalovszki, A.; Angelidaki, I. Anaerobic Co-digestion of Agricultural Byproducts with Manure for Enhanced Biogas Production. Energy Fuels 2015, 29, 8088-8094. [CrossRef]

71. Li, J.X.; Wang, L.A.; Zhan, X.Y.; Huang, C. Exploring the biogas production and microbial community from co-digestion of sewage sludge with municipal solid waste incineration fresh leachate. Int. J. Environ. Sci. Technol. 2021, 18, 901-912. [CrossRef]

72. Cabbai, V.; Ballico, M.; Aneggi, E.; Goi, D. BMP tests of source selected OFMSW to evaluate anaerobic codigestion with sewage sludge. Waste Manag. 2013, 33, 1626-1632. [CrossRef] [PubMed]

73. Wei, L.; Qin, K.; Ding, J.; Xue, M.; Yang, C.; Jiang, J.; Zhao, Q. Optimization of the co-digestion of sewage sludge, maize straw and cow manure: Microbial responses and effect of fractional organic characteristics. Sci. Rep. 2019, 9, 1-10. [CrossRef]

74. Li, P.; Cheng, C.; He, C.; Yu, R.; Shen, D.; Jiao, Y. Experimental study on anaerobic co-digestion of the individual component of biomass with sewage sludge: Methane production and microbial community. Biomass Convers. Biorefinery 2020, 1-14. [CrossRef]

75. Keucken, A.; Habagil, M.; Batstone, D.; Jeppsson, U.; Arnell, M. Anaerobic Co-Digestion of Sludge and Organic Food WastePerformance, Inhibition, and Impact on the Microbial Community. Energies 2018, 11, 2325. [CrossRef]

76. Pastor-Poquet, V.; Papirio, S.; Trably, E.; Rintala, J.; Escudié, R.; Esposito, G. High-solids anaerobic digestion requires a trade-off between total solids, inoculum-to-substrate ratio and ammonia inhibition. Int. J. Environ. Sci. Technol. 2019, 16, 7011-7024. [CrossRef]

77. Otero, M.; Lobato, A.; Cuetos, M.; Sánchez, M.; Gómez, X. Digestion of cattle manure: Thermogravimetric kinetic analysis for the evaluation of organic matter conversion. Bioresour. Technol. 2011, 102, 3404-3410. [CrossRef] [PubMed]

78. Mahato, P.; Goyette, B.; Rahaman, S.; Rajagopal, R. Processing High-Solid and High-Ammonia Rich Manures in a Two-Stage (Liquid-Solid) Low-Temperature Anaerobic Digestion Process: Start-Up and Operating Strategies. Bioengineering 2020, 7, 80. [CrossRef] [PubMed]

79. Gómez, X.; Meredith, W.; Fernández, C.; Sánchez-García, M.; Díez-Antolínez, R.; Garzón-Santos, J.; Snape, C.E. Evaluating the effect of biochar addition on the anaerobic digestion of swine manure: Application of Py-GC/MS. Environ. Sci. Pollut. Res. 2018, 25, 25600-25611. [CrossRef]

80. González, R.; Smith, R.; Blanco, D.; Fierro, J.; Gómez, X. Application of thermal analysis for evaluating the effect of glycerine addition on the digestion of swine manure. J. Therm. Anal. Calorim. 2018, 135, 2277-2286. [CrossRef]

81. Alrawashdeh, K.A.B.; Pugliese, A.; Slopiecka, K.; Pistolesi, V.; Massoli, S.; Bartocci, P.; Bidini, G.; Fantozzi, F. Codigestion of Untreated and Treated Sewage Sludge with the Organic Fraction of Municipal Solid Wastes. Fermentation 2017, 3, 35. [CrossRef]

82. Yoon, Y.; Lee, S.; Kim, K.; Jeon, T.; Shin, S. Study of anaerobic co-digestion on wastewater treatment sludge and food waste leachate using BMP test. J. Mater. Cycles Waste Manag. 2018, 20, 283-292. [CrossRef]

83. Takashima, M.; Yaguchi, J. High-solids thermophilic anaerobic digestion of sewage sludge: Effect of ammonia concentration. J. Mater. Cycles Waste Manag. 2021, 23, 205-213. [CrossRef] 
84. Fierro, J.; Martinez, E.J.; Rosas, J.G.; Fernández, R.A.; López, R.; Gomez, X. Co-Digestion of Swine Manure and Crude Glycerine: Increasing Glycerine Ratio Results in Preferential Degradation of Labile Compounds. Water Air Soil Pollut. 2016, $227,1-13$. [CrossRef]

85. Habagil, M.; Keucken, A.; Horváth, I.S. Biogas Production from Food Residues-The Role of Trace Metals and Co-Digestion with Primary Sludge. Environment 2020, 7, 42. [CrossRef]

86. Wang, F.; Pei, M.; Qiu, L.; Yao, Y.; Zhang, C.; Qiang, H. Performance of Anaerobic Digestion of Chicken Manure Under Gradually Elevated Organic Loading Rates. Int. J. Environ. Res. Public Health 2019, 16, 2239. [CrossRef]

87. Fierro, J.; Torres, E.J.M.; Rosas, J.G.; Blanco, D.; Gómez, X.; Blanco-Cobián, D. Anaerobic codigestion of poultry manure and sewage sludge under solid-phase configuration. Environ. Prog. Sustain. Energy 2013, 33, 866-872. [CrossRef]

88. Blanco, D.; Lobato, A.; Fernández, C.; Escapa, A.; Gómez, X. Batch dry anaerobic codigestion of sheep manure and potato waste. In Proceedings of the 14th RAMIRAN International Conference, Lisboa, Portugal, 13-15 September 2010.

89. Xing, T.; Kong, X.; Dong, P.; Zhen, F.; Sun, Y. Leachate recirculation effects on solid-state anaerobic digestion of Pennisetum hybrid and microbial community analysis. J. Chem. Technol. Biotechnol. 2019, 95, 1216-1224. [CrossRef]

90. Kusch, S.; Oechsner, H.; Jungbluth, T. Biogas production with horse dung in solid-phase digestion systems. Bioresour. Technol. 2008, 99, 1280-1292. [CrossRef]

91. Nomanbhay, S.; Ong, M.Y.; Chew, K.W.; Show, P.-L.; Lam, M.K.; Chen, W.-H. Organic Carbonate Production Utilizing Crude Glycerol Derived as By-Product of Biodiesel Production: A Review. Energies 2020, 13, 1483. [CrossRef]

92. Takeda, P.Y.; Gotardo, J.T.; Gomes, S.D. Anaerobic Co-digestion of Leachate and Glycerol for Renewable Energy Generation. Environ. Technol. 2020, 1-28. [CrossRef]

93. Ferreira, J.D.S.; Volschan, I.; Cammarota, M.C. Co-digestion of sewage sludge with crude or pretreated glycerol to increase biogas production. Environ. Sci. Pollut. Res. 2018, 25, 21811-21821. [CrossRef]

94. Astals, S.; Nolla-Ardèvol, V.; Mata-Alvarez, J. Thermophilic co-digestion of pig manure and crude glycerol: Process per-formance and digestate stability. J. Biotechnol. 2013, 166, 97-104. [CrossRef]

95. Paulista, L.O.; Boaventura, R.A.; Vilar, V.J.; Pinheiro, A.L.; Martins, R.J. Enhancing methane yield from crude glycerol an-aerobic digestion by coupling with ultrasound or A. niger/E. coli biodegradation. Environ. Sci. Pollut. Res. 2020, 27, 1461-1474. [CrossRef]

96. Huber, D.H.; Ramirez-Garcia, A.; Chavarria-Palma, J.E.; Espinosa-Solares, T.; Noundou, V.L.; Montenegro-Garcia, N.A.; Adeleye, A.; Martin, C.S. Stress induced by crude glycerol in a thermophilic digester: Microbial community divergence and resilience, but slow process recovery. Appl. Microbiol. Biotechnol. 2020, 104, 10769-10781. [CrossRef]

97. González, R.; González, J.; Rosas, J.G.; Smith, R.; Gómez, X. Biochar and Energy Production: Valorizing Swine Manure through Coupling Co-Digestion and Pyrolysis. C-J. Carbon Res. 2020, 6, 43. [CrossRef]

98. Zahedi, S.; Martín, C.; Solera, R.; Pérez, M. Evaluating the Effectiveness of Adding Chicken Manure in the Anaerobic Mesophilic Codigestion of Sewage Sludge and Wine Distillery Wastewater: Kinetic Modeling and Economic Approach. Energy Fuels 2020, 34, 12626-12633. [CrossRef]

99. Cuetos, M.; Gómez, X.; Torres, E.J.M.; Fierro, J.; Otero, M. Feasibility of anaerobic co-digestion of poultry blood with maize residues. Bioresour. Technol. 2013, 144, 513-520. [CrossRef] [PubMed]

100. Qian, M.; Zhang, Y.; Li, R.; Nelles, M.; Stinner, W.; Li, Y. Effects of Percolate Recirculation on Dry Anaerobic Co-digestion of Organic Fraction of Municipal Solid Waste and Corn Straw. Energy Fuels 2017, 31, 12183-12191. [CrossRef]

101. Degueurce, A.; Trémier, A.; Peu, P. Dynamic effect of leachate recirculation on batch mode solid state anaerobic digestion: Influence of recirculated volume, leachate to substrate ratio and recirculation periodicity. Bioresour. Technol. 2016, 216, 553-561. [CrossRef] [PubMed]

102. Petracchini, F.; Liotta, F.; Paolini, V.; Perilli, M.; Cerioni, D.; Gallucci, F.; Carnevale, M.; Bencini, A. A novel pilot scale mul-tistage semidry anaerobic digestion reactor to treat food waste and cow manure. Int. J. Environ. Sci. Technol. 2018, 15, 1999-2008. [CrossRef]

103. Bardi, M.J.; Rad, H.A. Simultaneous synergistic effects of addition of agro-based adsorbent on anaerobic co-digestion of food waste and sewage sludge. J. Mater. Cycles Waste Manag. 2019, 22, 65-79. [CrossRef]

104. Achi, C.G.; Hassanein, A.; Lansing, S. Enhanced Biogas Production of Cassava Wastewater Using Zeolite and Biochar Additives and Manure Co-Digestion. Energies 2020, 13, 491. [CrossRef]

105. Cuetos, M.J.; Martinez, E.J.; Moreno, R.; Gonzalez, R.; Otero, M.; Gomez, X. Enhancing anaerobic digestion of poultry blood using activated carbon. J. Adv. Res. 2017, 8, 297-307. [CrossRef]

106. Cerrillo, M.; Viñas, M.; Bonmatí, A. Anaerobic digestion and electromethanogenic microbial electrolysis cell integrated system: Increased stability and recovery of ammonia and methane. Renew. Energy 2018, 120, 178-189. [CrossRef]

107. Martínez, E.J.; Rosas, J.G.; Sotres, A.; Moran, A.; Cara, J.; Sánchez, M.E.; Gómez, X. Codigestion of sludge and citrus peel wastes: Evaluating the effect of biochar addition on microbial communities. Biochem. Eng. J. 2018, 137, 314-325. [CrossRef]

108. Arenas, C.B.; Meredith, W.; Snape, C.E.; Gómez, X.; González, J.F.; Martinez, E.J. Effect of char addition on anaerobic digestion of animal by-products: Evaluating biogas production and process performance. Environ. Sci. Pollut. Res. 2020, 27, 24387-24399. [CrossRef]

109. Cui, Y.; Mao, F.; Zhang, J.; He, Y.; Tong, Y.W.; Peng, Y. Biochar enhanced high-solid mesophilic anaerobic digestion of food waste: Cell viability and methanogenic pathways. Chemosphere 2021, 272, 129863. [CrossRef] [PubMed] 
110. Liu, W.; Cai, W.; Guo, Z.; Wang, L.; Yang, C.; Varrone, C.; Wang, A. Microbial electrolysis contribution to anaerobic digestion of waste activated sludge, leading to accelerated methane production. Renew. Energy 2016, 91, 334-339. [CrossRef]

111. Moreno, R.; Martínez, E.J.; Escapa, A.; Martínez, O.; Díez-Antolínez, R.; Gómez, X. Mitigation of Volatile Fatty Acid Build-Up by the Use of Soft Carbon Felt Electrodes: Evaluation of Anaerobic Digestion in Acidic Conditions. Fermentation 2018, 4, 2. [CrossRef]

112. Gómez, X.; Cuetos, M.J.; Tartakovsky, B.; Martinez-Nunez, M.F.; Morán, A. A comparison of analytical techniques for eval-uating food waste degradation by anaerobic digestion. Bioprocess Biosyst. Eng. 2010, 33, 427-438. [CrossRef] [PubMed]

113. Nges, I.A.; Liu, J. Effects of solid retention time on anaerobic digestion of dewatered-sewage sludge in mesophilic and thermophilic conditions. Renew. Energy 2010, 35, 2200-2206. [CrossRef]

114. Gebreeyessus, G.D.; Jenicek, P. Thermophilic versus Mesophilic Anaerobic Digestion of Sewage Sludge: A Comparative Review. Bioenginering 2016, 3, 15. [CrossRef] [PubMed]

115. Nielsen, B.; Petersen, G. Thermophilic anaerobic digestion and pasteurisation. Practical experience from Danish wastewater treatment plants. Water Sci. Technol. 2000, 42, 65-72. [CrossRef]

116. De Vrieze, J.; Smet, D.; Klok, J.; Colsen, J.; Angenent, L.T.; Vlaeminck, S.E. Thermophilic sludge digestion improves energy balance and nutrient recovery potential in full-scale municipal wastewater treatment plants. Bioresour. Technol. 2016, 218, 1237-1245. [CrossRef] [PubMed]

117. Banks, C.J.; Chesshire, M.; Stringfellow, A. A pilot-scale comparison of mesophilic and thermophilic digestion of source segregated domestic food waste. Water Sci. Technol. 2008, 58, 1475-1481. [CrossRef]

118. Silvestre, G.; Fernández, B.; Bonmatí, A. Addition of crude glycerine as strategy to balance the $\mathrm{C} / \mathrm{N}$ ratio on sewage sludge thermophilic and mesophilic anaerobic co-digestion. Bioresour. Technol. 2015, 193, 377-385. [CrossRef] [PubMed]

119. Chen, Z.; Li, W.; Qin, W.; Sun, C.; Wang, J.; Wen, X. Long-term performance and microbial community characteristics of pilot-scale anaerobic reactors for thermal hydrolyzed sludge digestion under mesophilic and thermophilic conditions. Sci. Total. Environ. 2020, 720, 137566. [CrossRef]

120. Gómez, X.; Blanco, D.; Lobato, A.; Calleja, A.; Martínez-Núñez, F.; Martin-Villacorta, J. Digestion of cattle manure under mesophilic and thermophilic conditions: Characterization of organic matter applying thermal analysis and $1 \mathrm{H} \mathrm{NMR.} \mathrm{Bio-}$ geochemestry 2010, 22, 623-635. [CrossRef]

121. Provenzano, M.R.; Malerba, A.D.; Buscaroli, A.; Zannoni, D.; Senesi, N. Anaerobic digestion of municipal solid waste and sewage sludge under mesophilic and thermophilic conditions. J. Therm. Anal. Calorim. 2012, 111, 1861-1870. [CrossRef]

122. Wang, G.; Li, Q.; Gao, X.; Wang, X.C. Sawdust-Derived Biochar Much Mitigates VFAs Accumulation and Improves Microbial Activities To Enhance Methane Production in Thermophilic Anaerobic Digestion. ACS Sustain. Chem. Eng. 2018, 7, 2141-2150. [CrossRef]

123. Migliori, M.; Catizzone, E.; Giordano, G.; Le Pera, A.; Sellaro, M.; Lista, A.; Zanardi, G.; Zoia, L. Pilot plant data assessment in anaerobic digestion of organic fraction of municipal waste solids. Processes 2019, 7, 54. [CrossRef]

124. Nwokolo, N.; Mukumba, P.; Obileke, K.; Enebe, M. Waste to energy: A focus on the impact of substrate type in biogas pro-duction. Processes 2020, 8, 1224. [CrossRef]

125. Shen, M.; Zhang, Y.; Hu, D.; Fan, J.; Zeng, G. A review on removal of siloxanes from biogas: With a special focus on volatile methylsiloxanes. Environ. Sci. Pollut. Res. 2018, 25, 30847-30862. [CrossRef] [PubMed]

126. Adnan, A.I.; Ong, M.Y.; Nomanbhay, S.; Chew, K.W.; Show, P.L. Technologies for Biogas Upgrading to Biomethane: A Review. Bioenginering 2019, 6, 92. [CrossRef]

127. Angelidaki, I.; Xie, L.; Luo, G.; Zhang, Y.; Oechsner, H.; Lemmer, A.; Munoz, R.; Kougias, P.G. Biogas Upgrading: Current and Emerging Technologies. In Biofuels: Alternative Feedstocks and Conversion Processes for the Production of Liquid and Gaseous Biofuels; Elsevier BV: Amsterdam, The Netherlands, 2019; pp. 817-843.

128. Kapoor, R.; Ghosh, P.; Kumar, M.; Vijay, V.K. Evaluation of biogas upgrading technologies and future perspectives: A review. Environ. Sci. Pollut. Res. 2019, 26, 11631-11661. [CrossRef]

129. Dezham, P.; Rosenblum, E.; Jenkins, D. Digester gas control using iron salts. J. Water Pollut. Control Fed. $1988,514-517$.

130. Erdirencelebi, D.; Kucukhemek, M. Control of hydrogen sulphide in full-scale anaerobic digesters using iron (III) chloride: Performance, origin and effects. Water SA 2018, 44, 176-183. [CrossRef]

131. Schaumann BioEnergy GmbH. BC.ATOX Scon. Available online: https://www.schaumann-bioenergy.com/en/bc_atox_scon. html (accessed on 5 February 2021).

132. Schaumann BioEnergy GmbH. BC.ATOX liquid. Available online: https://www.schaumann-bioenergy.com/en/bc_atox_liquid. html (accessed on 5 February 2021).

133. Okoro, O.V.; Sun, Z. Desulphurisation of biogas: A systematic qualitative and economic-based quantitative review of alter-native strategies. Chem. Eng. 2019, 3, 76. [CrossRef]

134. Interra Global Corp. $\mathrm{H}_{2} \mathrm{~S}$ Removal Media. Available online: https://www.interraglobal.com/products/other/h2sremoval-media/?gclid=Cj0KCQjw38-DBhDpARIsADJ3kjmluUPQJYhXJh3Ol5ij6uVg485IvgK_90i7wuKPxQ0DitCOTyb_ OaAvakEALwwcB (accessed on 10 April 2021).

135. KRONOS Ecochem ${ }^{\circledR}$. Biogas Desulfurisation. Available online: https://kronosecochem.com/en/applications/biogas/ biogasentschwefelung-en/ (accessed on 10 April 2021).

136. Syed, M.; Soreanu, G.; Falletta, P.; Béland, M. Removal of hydrogen sulfide from gas streams using biological processes: A review. Can. Biosyst. Eng. 2006, 48, 2. 
137. Krayzelova, L.; Bartacek, J.; Díaz, I.; Jeison, D.; Volcke, E.I.P.; Jenicek, P. Microaeration for hydrogen sulfide removal during anaerobic treatment: A review. Rev. Environ. Sci. Bio/Technol. 2015, 14, 703-725. [CrossRef]

138. Nguyen, D.; Khanal, S.K. A little breath of fresh air into an anaerobic system: How microaeration facilitates anaerobic di-gestion process. Biotechnol. Adv. 2018, 36, 1971-1983. [CrossRef] [PubMed]

139. Bauer, F.; Persson, T.; Hulteberg, C.; Tamm, D. Biogas upgrading-technology overview, comparison and perspectives for the future. Biofuels Bioprod. Biorefining 2013, 7, 499-511. [CrossRef]

140. Orlygsson, J.; Scully, S.M. Influence of inhibitory compounds on biofuel production from oxalate-rich rhubarb leaf hydrol-ysates using Thermoanaerobacter thermohydrosulfuricus strain AK91. Fuels 2021, 2, 71-86. [CrossRef]

141. Di Iorio, S.; Magno, A.; Mancaruso, E.; Vaglieco, B.M. Performance, Gaseous and Particle Emissions of a Small Compression Ignition Engine Operating in Diesel/Methane Dual Fuel Mode. SAE Tech. Pap. Ser. 2016, 1. [CrossRef]

142. Abu Mansor, M.R.; Abbood, M.M.; Mohamad, T.I. The influence of varying hydrogen-methane-diesel mixture ratio on the combustion characteristics and emissions of a direct injection diesel engine. Fuel 2017, 190, 281-291. [CrossRef]

143. Cardone, M.; Marialto, R.; Ianniello, R.; Lazzaro, M.; Di Blasio, G. Spray Analysis and Combustion Assessment of Diesel-LPG Fuel Blends in Compression Ignition Engine. Fuels 2021, 2, 1-15. [CrossRef]

144. Feng, Q.; Lin, Y. Integrated processes of anaerobic digestion and pyrolysis for higher bioenergy recovery from lignocellulosic biomass: A brief review. Renew. Sustain. Energy Rev. 2017, 77, 1272-1287. [CrossRef]

145. Dussan, K.; Monaghan, R.F.D. Integrated Thermal Conversion and Anaerobic Digestion for Sludge Management in Wastewater Treatment Plants. Waste Biomass Valorization 2017, 9, 65-85. [CrossRef]

146. Ghysels, S.; Acosta, N.; Estrada, A.; Pala, M.; De Vrieze, J.; Ronsse, F.; Rabaey, K. Integrating anaerobic digestion and slow pyrolysis improves the product portfolio of a cocoa waste biorefinery. Sustain. Energy Fuels 2020, 4, 3712-3725. [CrossRef]

147. Deng, C.; Lin, R.; Kang, X.; Wu, B.; O'Shea, R.; Murphy, J.D. Improving gaseous biofuel yield from seaweed through a cascading circular bioenergy system integrating anaerobic digestion and pyrolysis. Renew. Sustain. Energy Rev. 2020, 128, 109895. [CrossRef]

148. González-Arias, J.; Gil, M.V.; Fernández, R.Á.; Martínez, E.J.; Fernández, C.; Papaharalabos, G.; Gómez, X. Integrating an-aerobic digestion and pyrolysis for treating digestates derived from sewage sludge and fat wastes. Environ. Sci. Pollut. Res. 2020, 27, 32603-32614. [CrossRef]

149. Papurello, D.; Gandiglio, M.; Kafashan, J.; Lanzini, A. Biogas Purification: A Comparison of Adsorption Performance in D4 Siloxane Removal Between Commercial Activated Carbons and Waste Wood-Derived Char Using Isotherm Equations. Processes 2019, 7, 774. [CrossRef]

150. Tinnirello, M.; Papurello, D.; Santarelli, M.; Fiorilli, S. Thermal Activation of Digested Sewage Sludges for Carbon Dioxide Removal from Biogas. Fuels 2020, 1, 30-46. [CrossRef]

151. Spanish Regulation. Available online: https://www.boe.es/eli/es/res/2018/10/08/(3)) (accessed on 10 February 2021).

152. BOE-A-1998-23284. Available online: https://www.boe.es/eli/es/1/1998/10/07/34/con (accessed on 10 April 2021).

153. Xu, M.; Lin, B. Exploring the "not in my backyard" effect in the construction of waste incineration power plants-Based on a survey in metropolises of China. Environ. Impact Assess. Rev. 2020, 82, 106377. [CrossRef]

154. Eurostat. SHARES (Renewables). Available online: https: / /ec.europa.eu/ eurostat/web/energy/data/shares (accessed on 10 April 2021).

155. The State of Renewable Energies in Europe. Available online: https://www.isi.fraunhofer.de/content/dam/isi/dokumente/ccx/ 2020/The-state-of-renewable-energies-in-Europe-2019.pdf (accessed on 10 April 2021).

156. García-Cascallana, J.; Gómez, X.; Martinez, E.J. Thermal Hydrolysis of Sewage Sludge: A Case Study of a WWTP in Burgos, Spain. Appl. Sci. 2021, 11, 964. [CrossRef]

157. Barber, W. Thermal hydrolysis for sewage treatment: A critical review. Water Res. 2016, 104, 53-71. [CrossRef]

158. Li, B.; Romero, A.; Wadhawan, T.; Tobin, M.; Manning, E.; Higgins, M.; Al-Omari, A.; Murthy, S.; Riffat, R.; De Clippeleir, H. Recuperative thickening for sludge retention time and throughput management in anaerobic digestion with thermal hy-drolysis pretreatment. Water Environ. Res. 2020, 92, 465-477. [CrossRef]

159. García-Cascallana, J.; Borge-Díez, D.; Gómez, X. Enhancing the efficiency of thermal hydrolysis process in wastewater treatment plants by the use of steam accumulation. Int. J. Environ. Sci. Technol. 2019, 16, 3403-3418. [CrossRef]

160. Available online: https://www.hielscher.com/sludge01.htm (accessed on 10 April 2021).

161. Biocrack II. Electrokinetic Disintegration. Available online: https://www.vogelsang.info/int/products/disintegration/biocrack/ (accessed on 15 April 2021).

162. Evoqua. Crown ${ }^{\mathrm{TM}}$ Disintegration System. Available online: https://www.evoqua.com/en/evoqua/products--services/ anaerobic-wastewater-treatment/digestor-components/crown-disintegration-system/ (accessed on 15 April 2021).

163. Wang, Q.; Wei, W.; Gong, Y.; Yu, Q.; Li, Q.; Sun, J.; Yuan, Z. Technologies for reducing sludge production in wastewater treatment plants: State of the art. Sci. Total Environ. 2017, 587-588, 510-521. [CrossRef]

164. Zhen, G.; Lu, X.; Kato, H.; Zhao, Y.; Li, Y.-Y. Overview of pretreatment strategies for enhancing sewage sludge disintegration and subsequent anaerobic digestion: Current advances, full-scale application and future perspectives. Renew. Sustain. Energy Rev. 2017, 69, 559-577. [CrossRef]

165. Wacławek, S.; Grübel, K.; Silvestri, D.; Padil, V.V.T.; Wacławek, M.; Černík, M.; Varma, R.S. Disintegration of Wastewater Activated Sludge (WAS) for Improved Biogas Production. Energies 2018, 12, 21. [CrossRef] 
166. Nguyen, V.K.; Chaudhary, D.K.; Dahal, R.H.; Trinh, N.H.; Kim, J.; Chang, S.W.; Hong, Y.; La, D.D.; Nguyen, X.C.; Ngo, H.H.; et al. Review on pretreatment techniques to improve anaerobic digestion of sewage sludge. Fuel 2021, 285, 119105. [CrossRef]

167. Akbulut, A. Techno-economic analysis of electricity and heat generation from farm-scale biogas plant: Çiçekdağı case study. Energy 2012, 44, 381-390. [CrossRef]

168. Aui, A.; Li, W.; Wright, M.M. Techno-economic and life cycle analysis of a farm-scale anaerobic digestion plant in Iowa. Waste Manag. 2019, 89, 154-164. [CrossRef]

169. Aryal, N.; Kvist, T. Alternative of Biogas Injection into the Danish Gas Grid System-A Study from Demand Perspective. ChemEngineering 2018, 2, 43. [CrossRef] 